\title{
اكتساب المنظمة للقدرات التنافسية في ظل التحديات الحديثة لإدارة الموارد البشرية التئية
}

Acquisition of competitiveness by the organization in the shadow of the modern challenges of human resources management

\author{
تاريخ الاستلام : 2019/08/24 ؛ تاريخ القبول : 2019/11/17
}

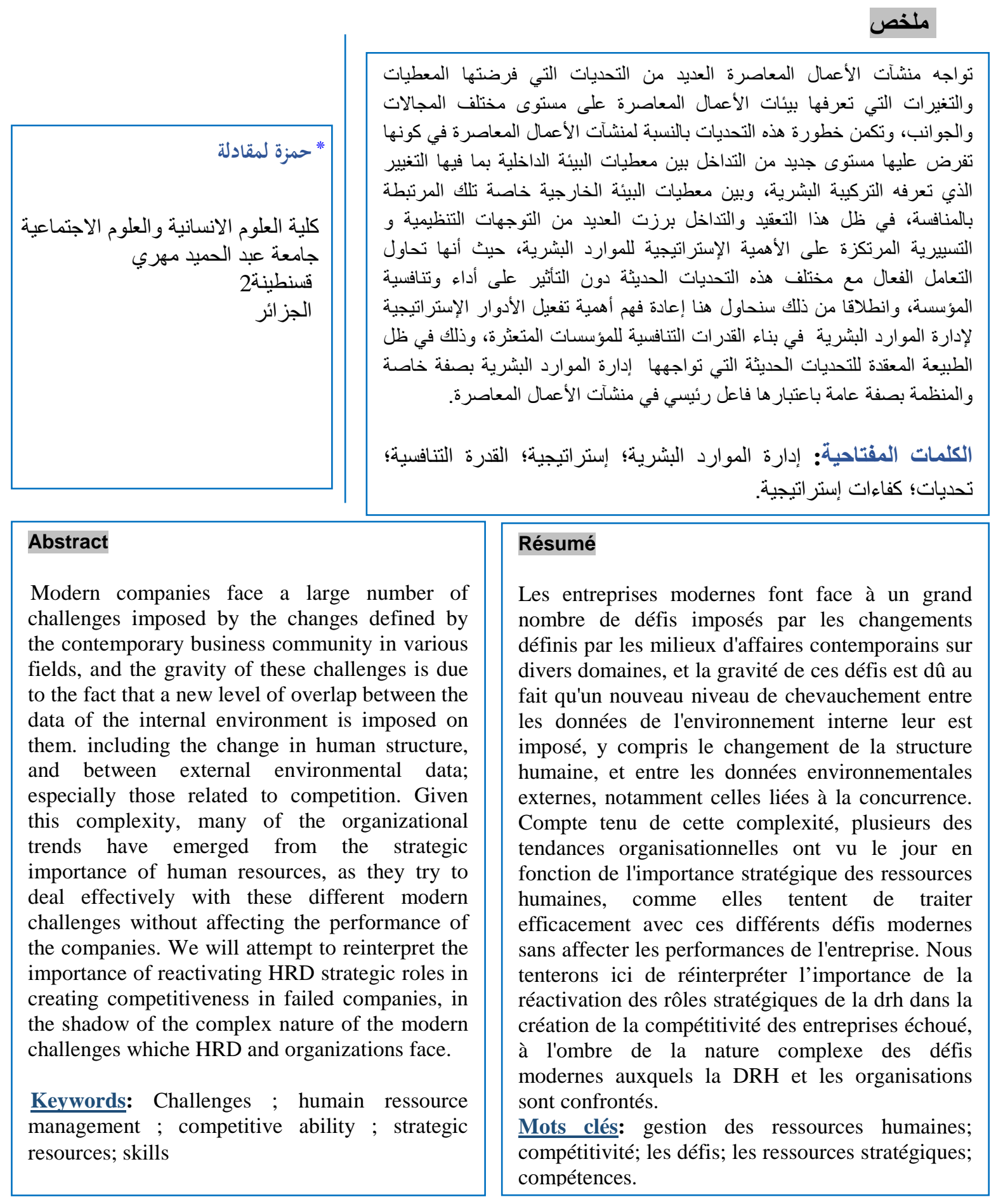

* Corresponding author, e-mail: hamza.lemgadla85@gmail.com

(C) جامعة الاخوة منتوري قسنطينة 1، الجزائر 2019. 


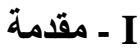

تعرف بيئات الأعمال الحديثة العديد من التغيرات التي تشمل مختلف الجوانب المرتبطة

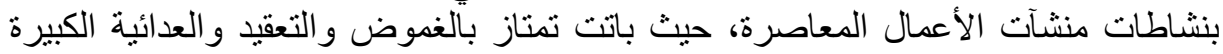

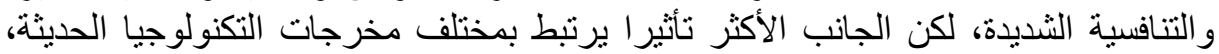

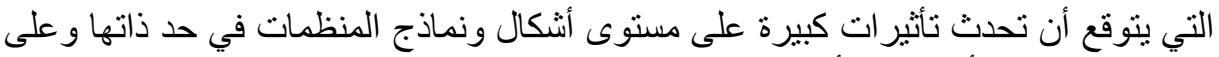

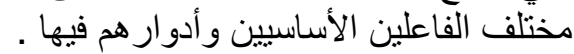

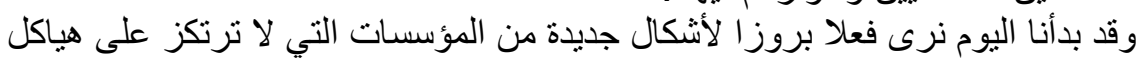

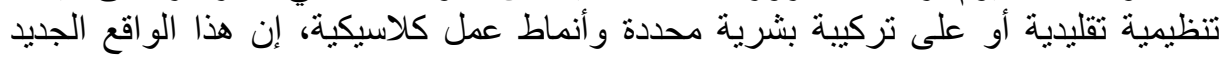

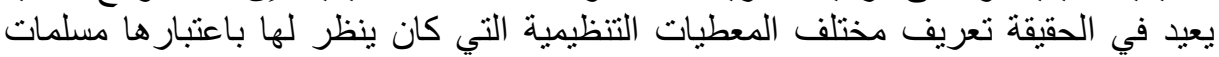

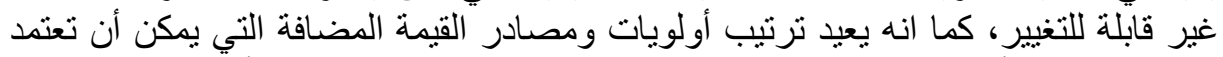

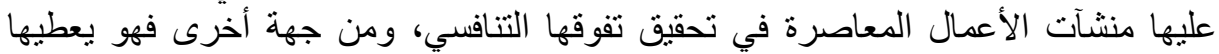

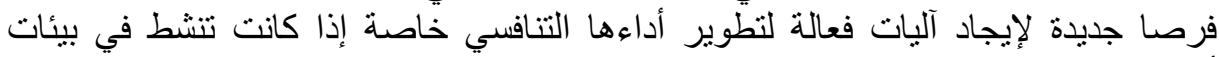

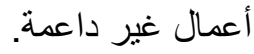

\section{طرح الإثكالية-II}

إن المنافسة الثديدة النتي تميز بيئة نشاط منشآت الأعمال المعاصرة زادت من الثات أهمية

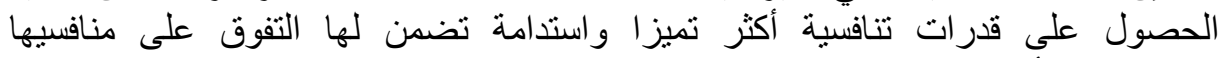

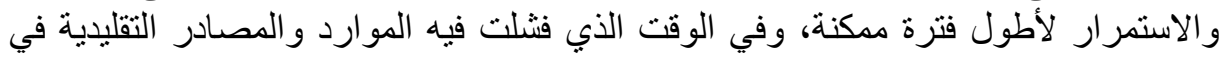

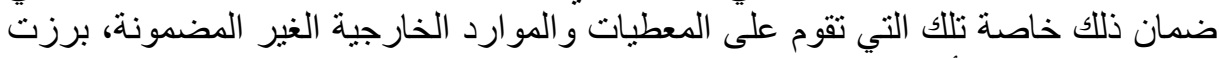

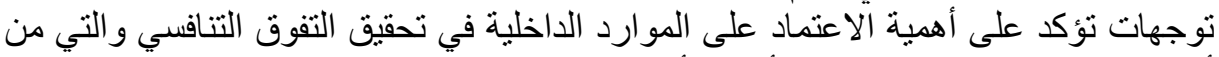

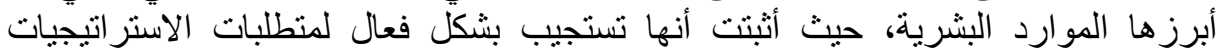

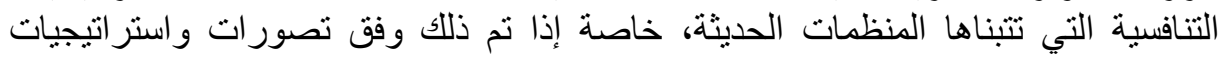

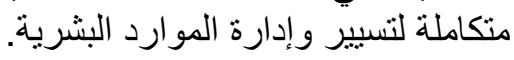

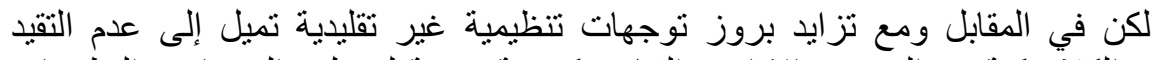

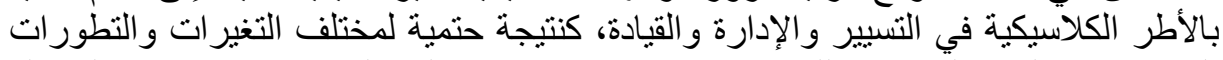

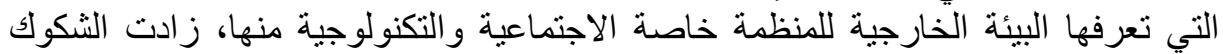

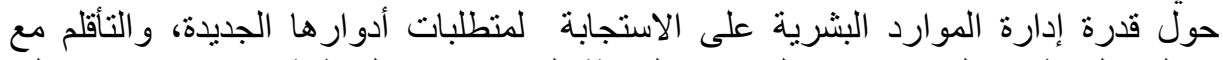

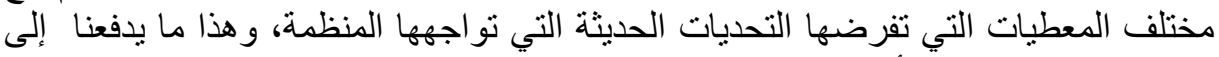

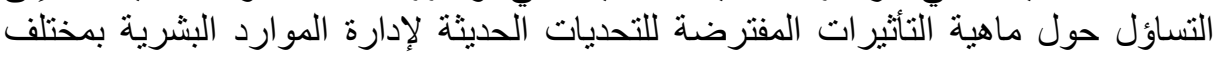

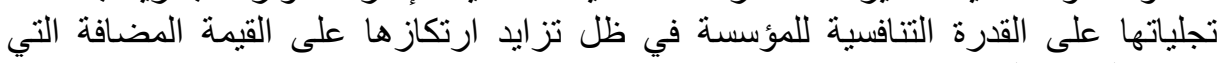

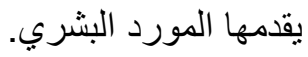

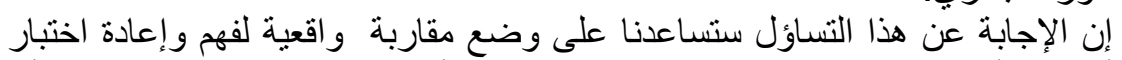

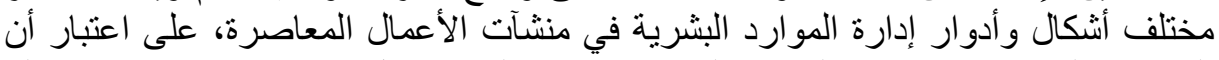

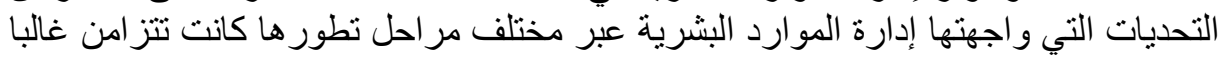

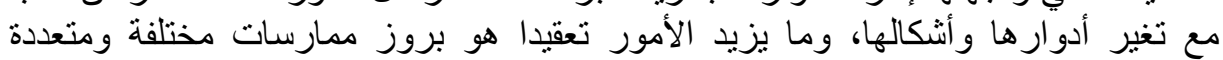

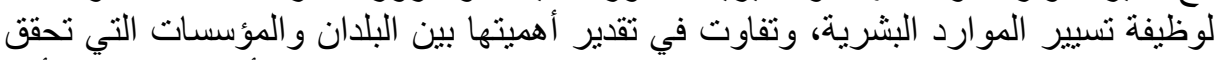

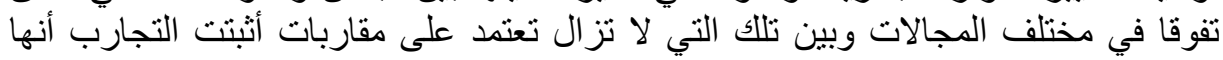

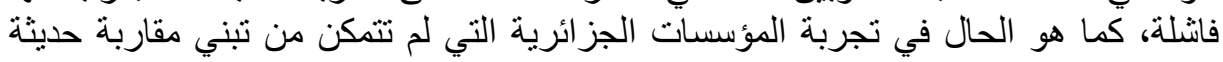

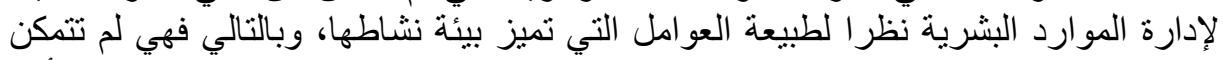

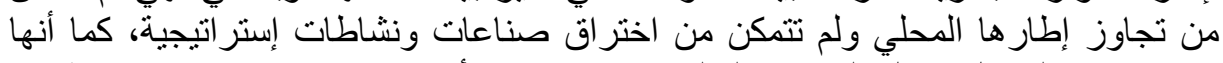

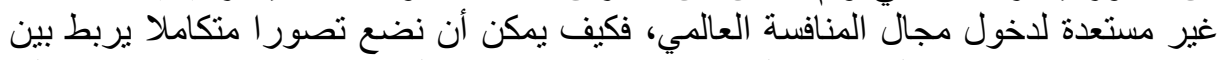

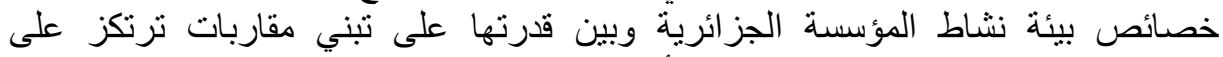

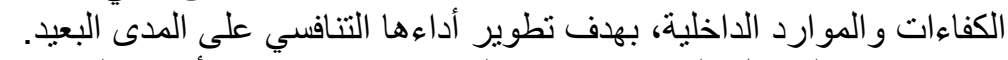

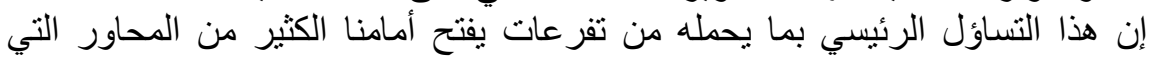

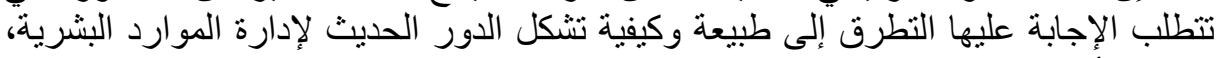

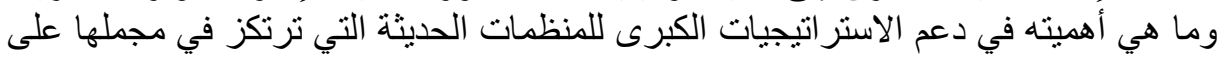




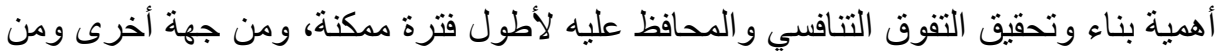

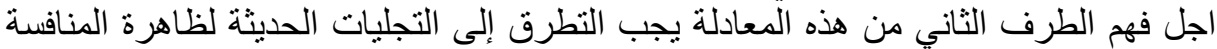

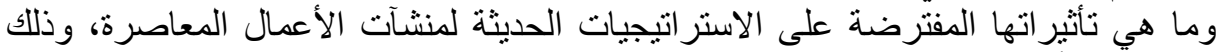

انطلاقا من أربعة مؤشر ات و وهي (1):

- القيمة: وهي تشمل ما يمكن أن يضيفه الاعنماد على المو ارد البشرية في بناء المزايا

التنافسية.

- الندرة: وهي تتعلق بالتميز التنافسي للموارد البشرية على مسنوى المهارات

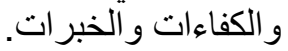

- ـ التقليد. وهي تتعلق بمدى صعوبة تقليد خصائص التميز التنافسي للوعاء البشري

لالمنظمة.

- - التنظيم: وهو يتعلق بمدى قدرة المنظمة على وضع اطر وبرامج لاستغلال الأمثل

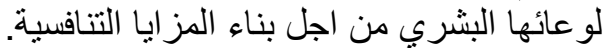

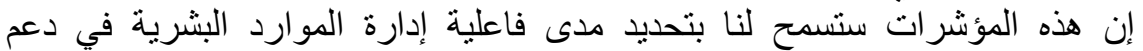

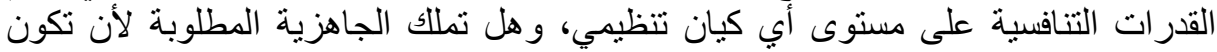

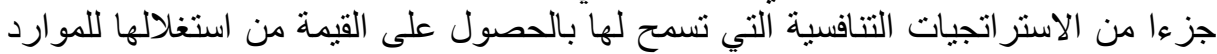

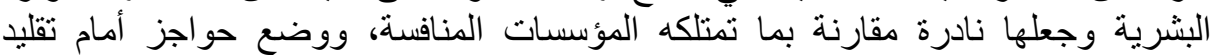

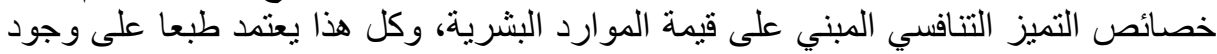

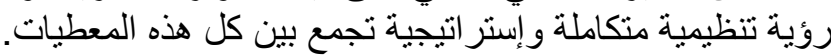

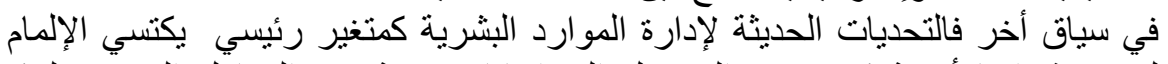

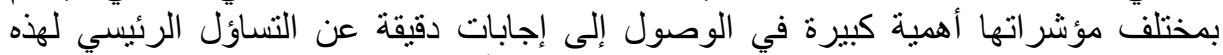

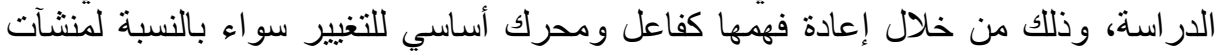

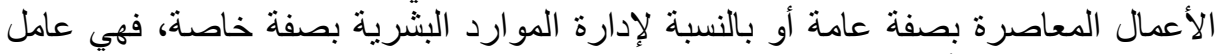

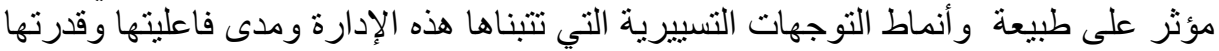

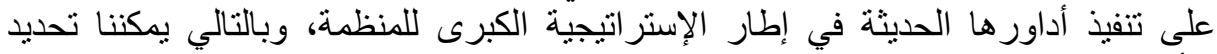

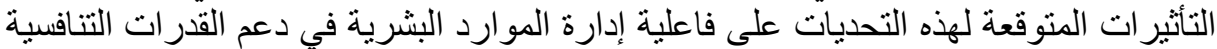

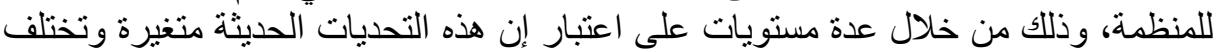

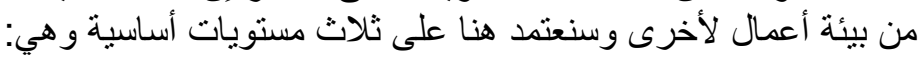

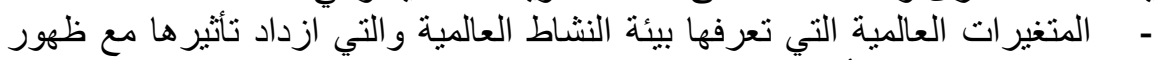

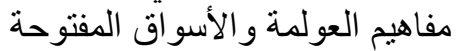

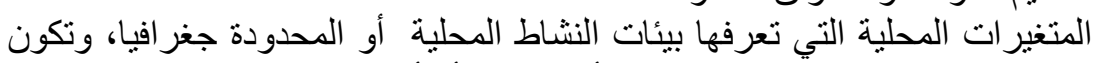

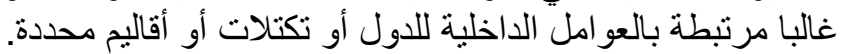

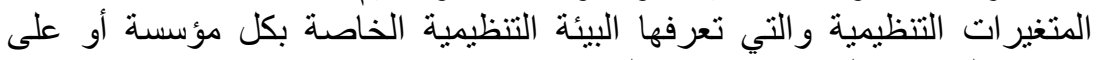
مستوى النماذج و المفاهيم الإدارية المستحدثة.

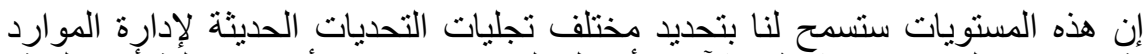

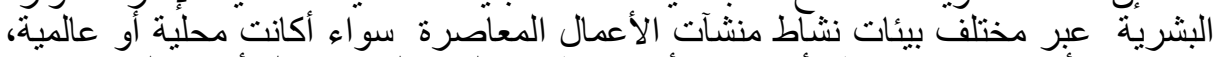

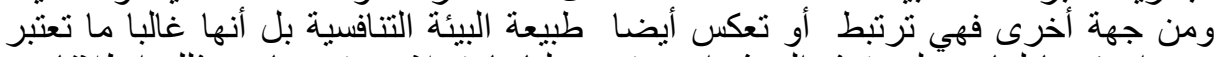

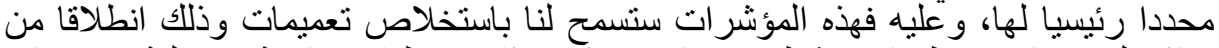

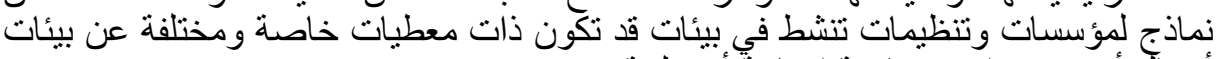
أعمال أخرى سؤست اء من ناحية ايجابيةً أو سلبية.

III - تحديد الدفاهيج الرئيسية:

1- 1إدرة الموارد البشرية الئية

هناك العديد من المداخل والمبل المقاربات التي حاولت إعطاء تعريفات شاملة لإدارة الموارد

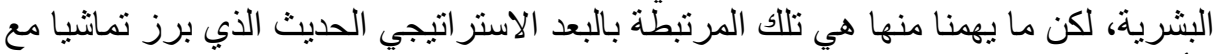

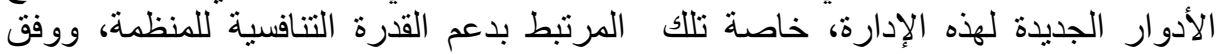

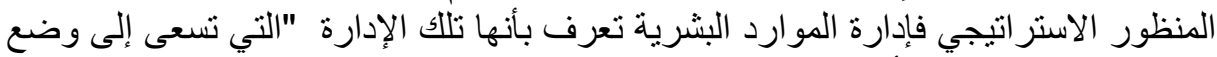

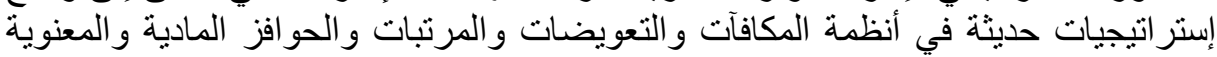

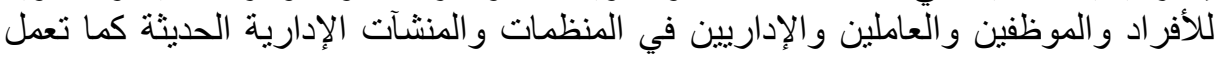




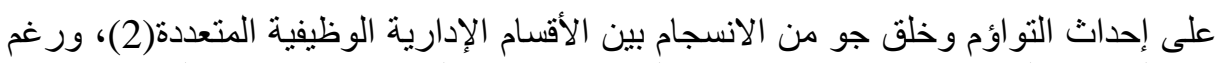

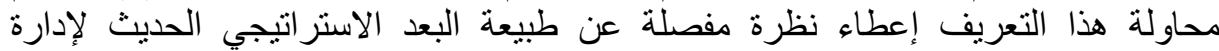

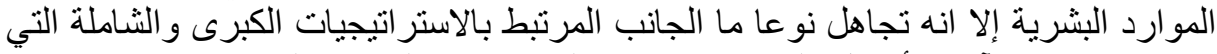

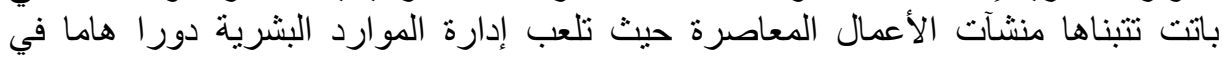
تجسيدها و إنجاحها.

ومن هذا المنطلق هناك من يرى إن إدارة الموارد البشرية تعرف بأنها تللك " الإدارة

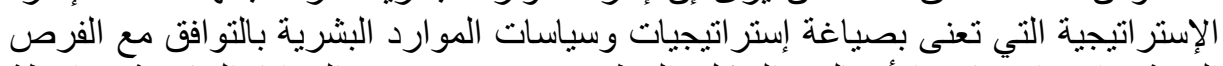

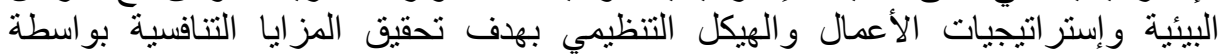

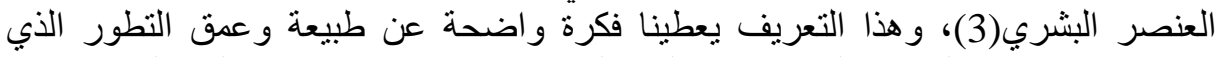

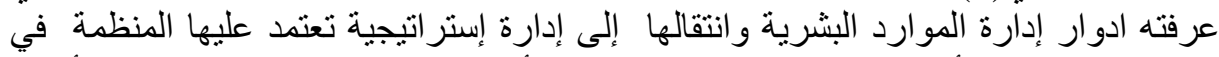

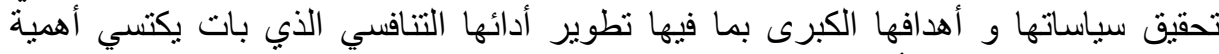
كبرى بالنسبة لمنشآت الأعمال المعاصرة. 2- 2 - 2 المنافسة و التنافسية:

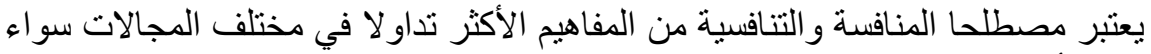

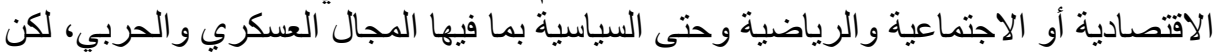

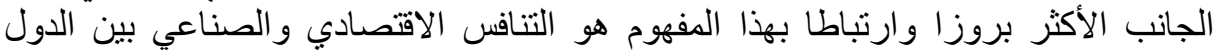

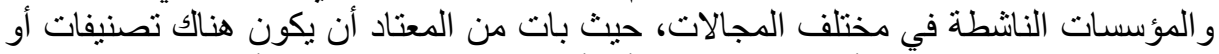

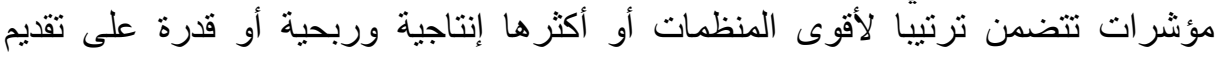

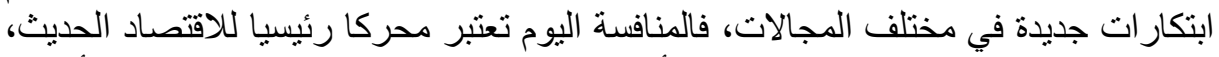

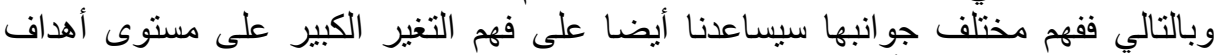
و واستر اتيجيات منشآت الأعمال المعاصرة.

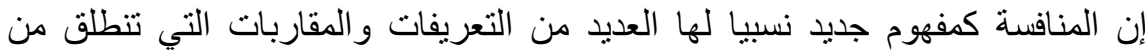

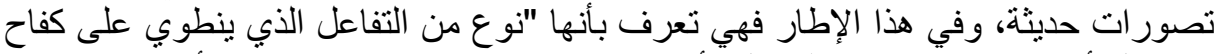

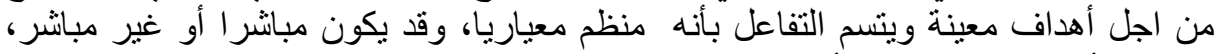

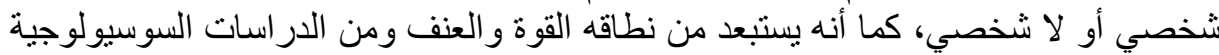

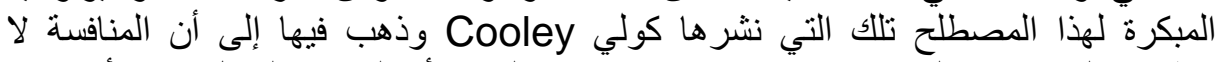

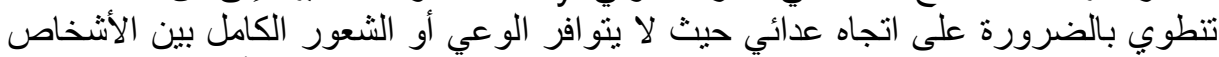

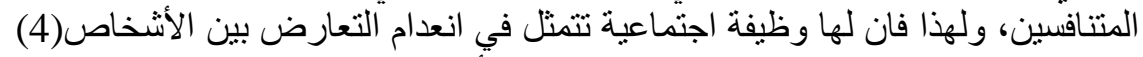

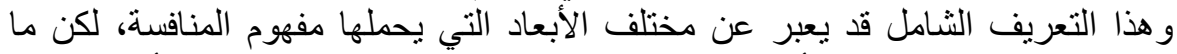

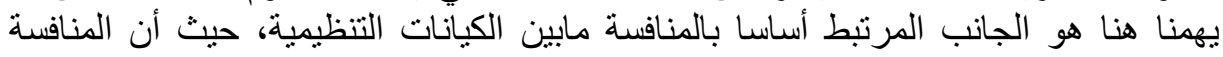

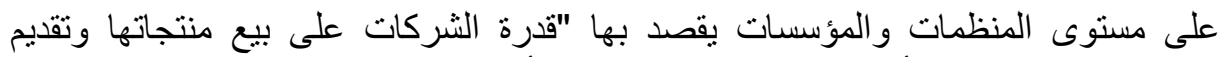

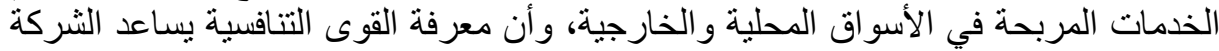

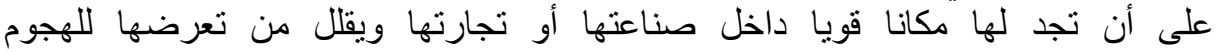

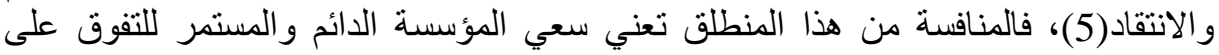

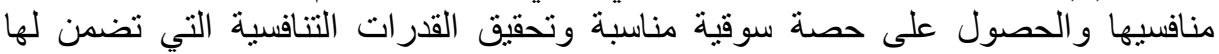

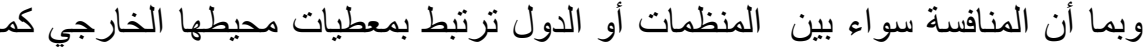

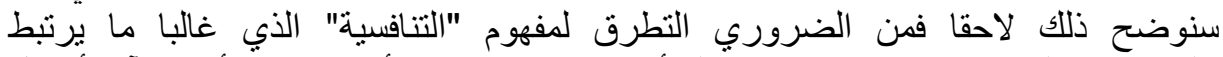

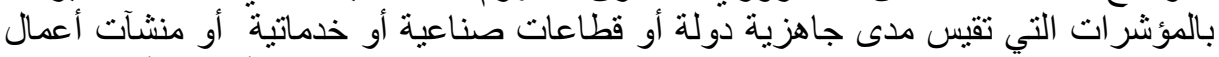

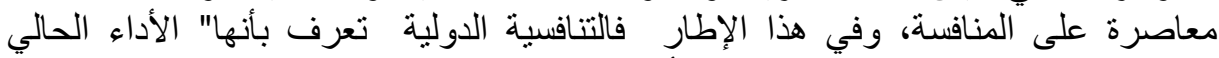

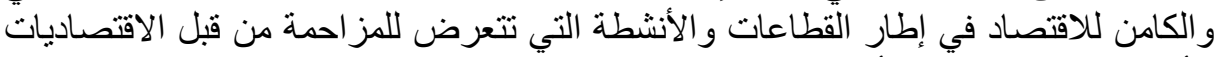

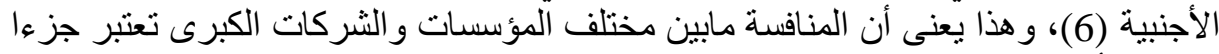

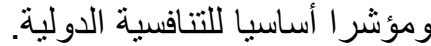

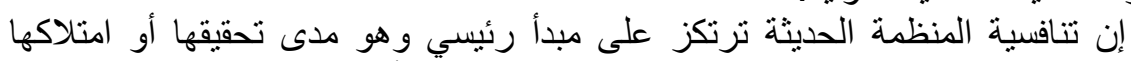

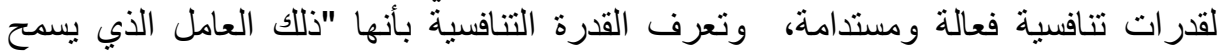

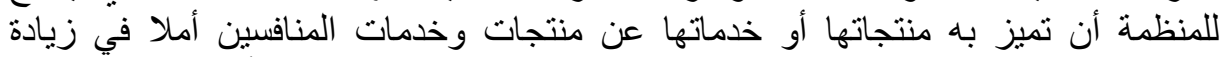

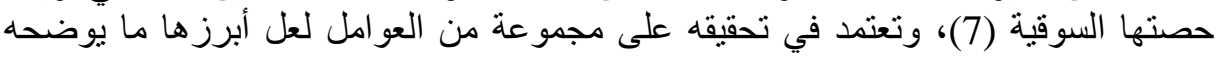


التعريف التالي الذي يرى" أنها تتحقق عندما يرى المشترون أن منتجات أو خدمات المنظمة التشئ

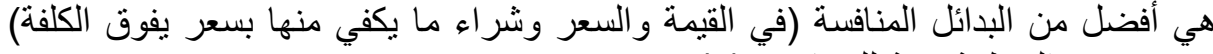

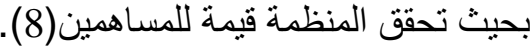

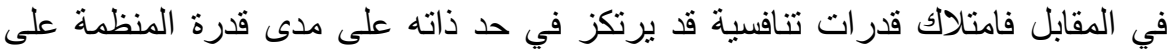

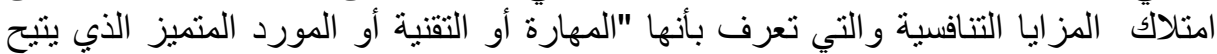

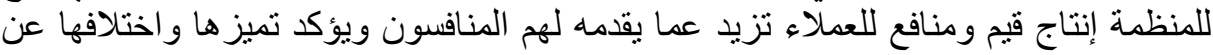

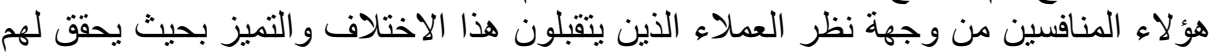

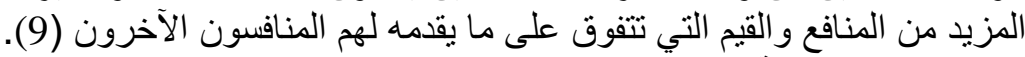

3- 3 - 3 التحديات الحديثة

يحمل مفهوم التحديات العديد من الخلفيات التي تمس جميع مجالات النشاط الإنساني

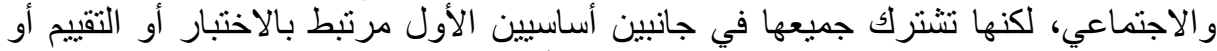

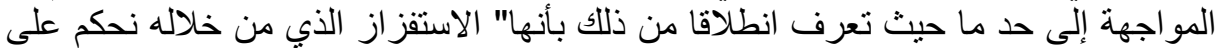

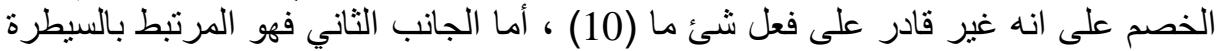

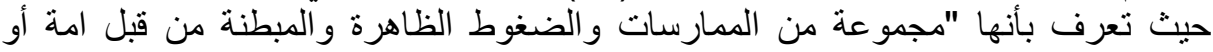

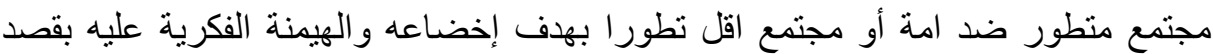

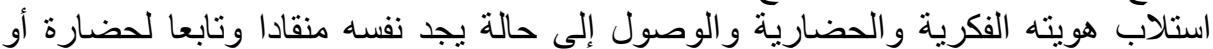

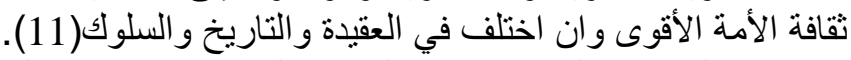

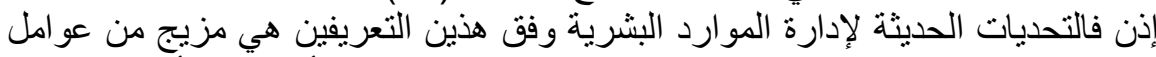

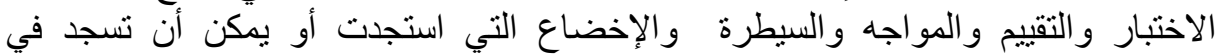

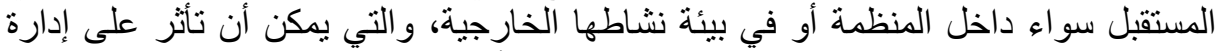

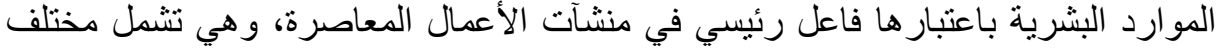

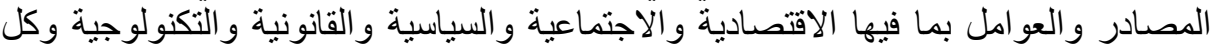
ما يتفرع عنها من عو امل ومتغير ات التهاتئ.

\section{-IV}

\section{1- بروز الدور الاستراتيجى وأهميته في دعم القدرة التنافسية للمؤسسة الحديثة:}

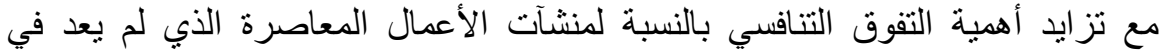

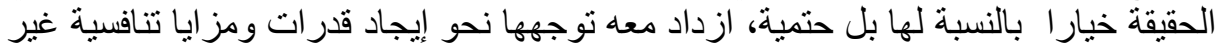

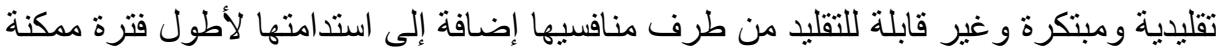

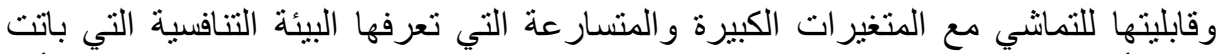

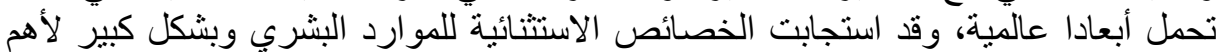

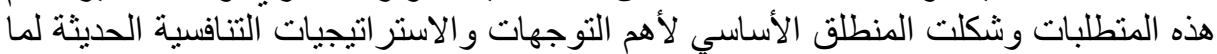

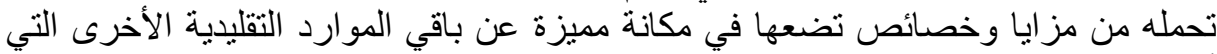

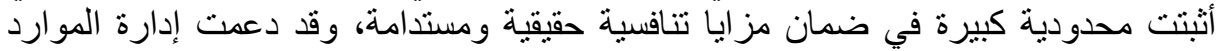

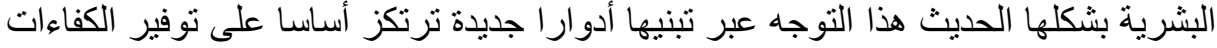

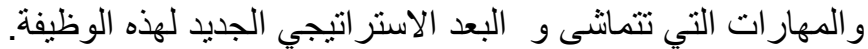

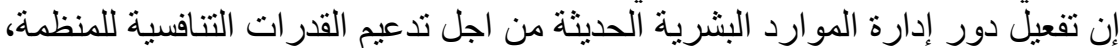

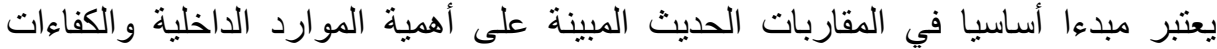

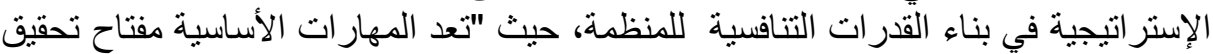

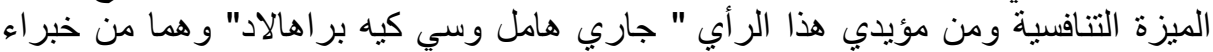

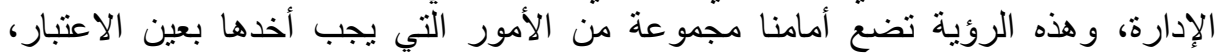

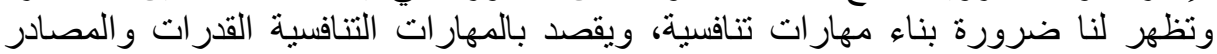

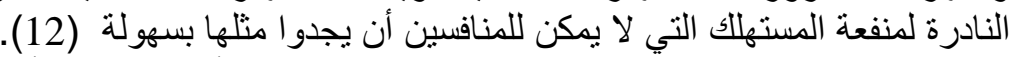

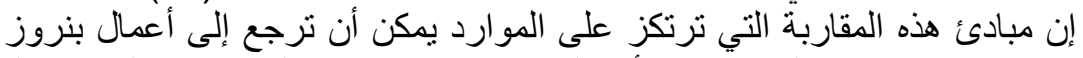

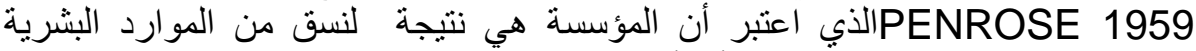

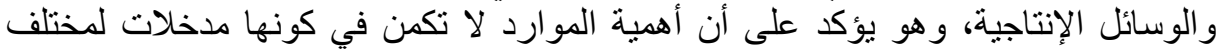

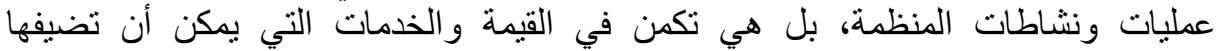




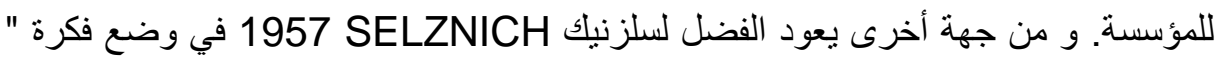

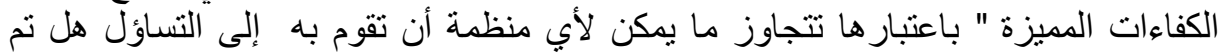

انجازه بطريقة جيدة (13).

وحسب المقاربة المرنكزة على الموارد فالمزايا التنافسية تنتج عن القوى الداخلية

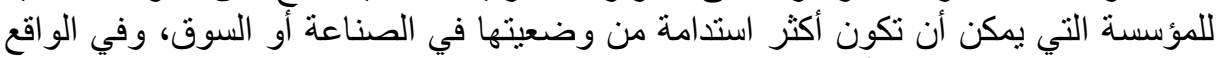

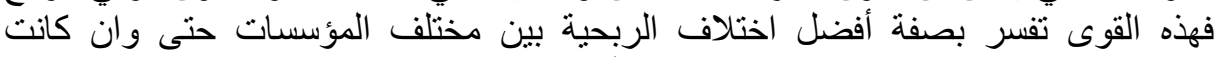

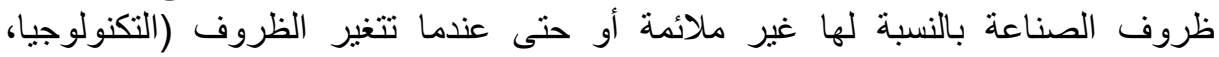

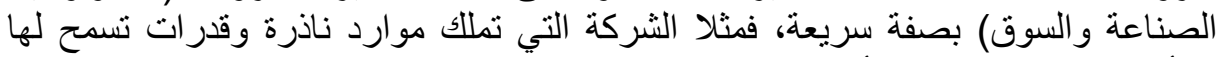

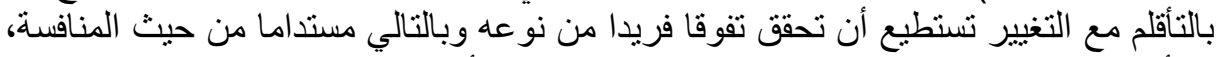

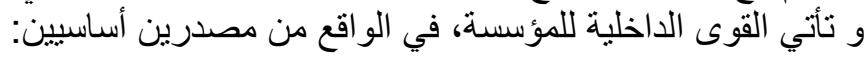

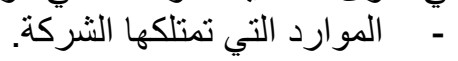

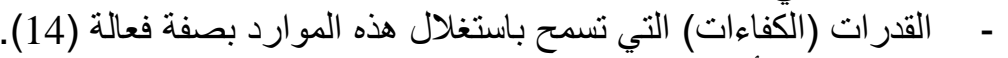

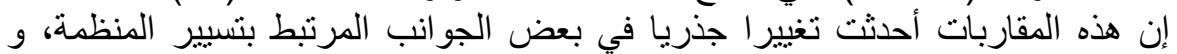

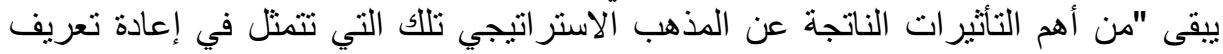

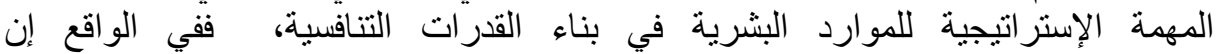

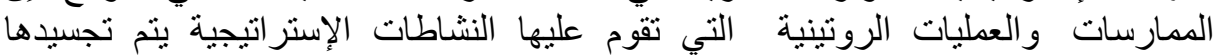

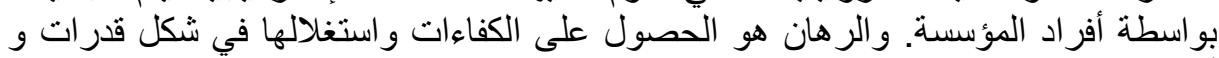

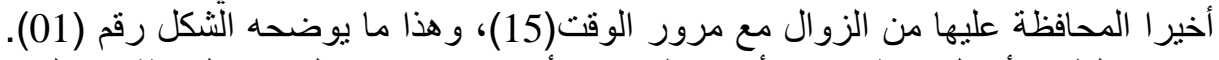

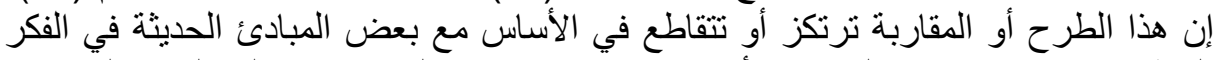

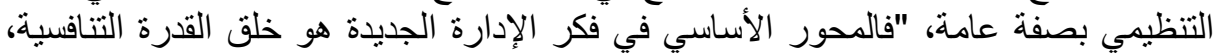

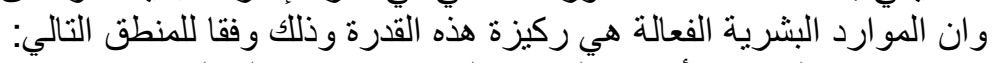

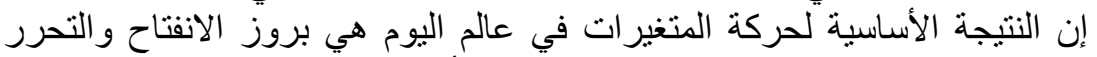
و المرونة كعناصر رئيسية في حركة منظمات الأعمال وكلها تؤدي إلى إنشعال قوى الأني

التنافس فيما بينها.

يتحدد مصير منظمة الأعمال في عالم اليوم وما قد تحققه من أرباح ونتائج على ما التهاء

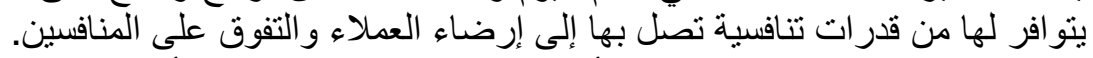

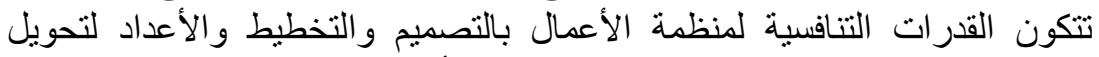

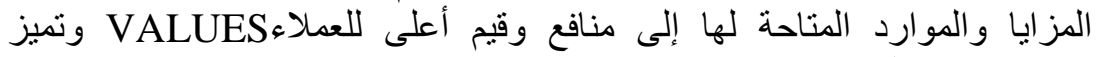

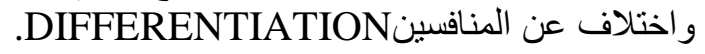

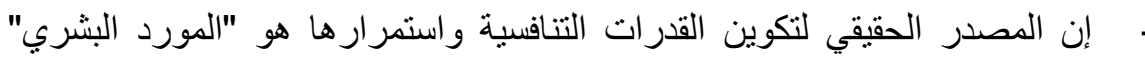

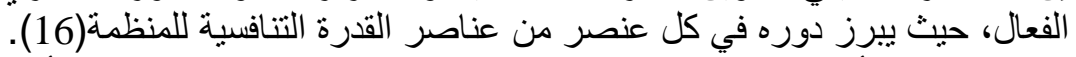

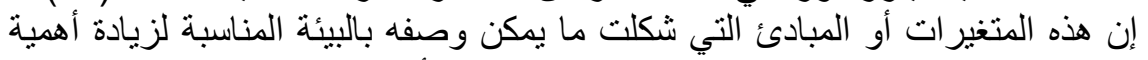

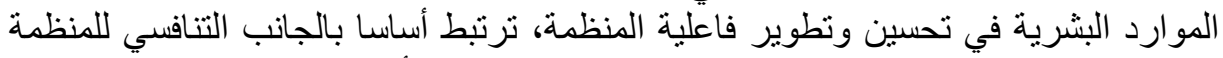

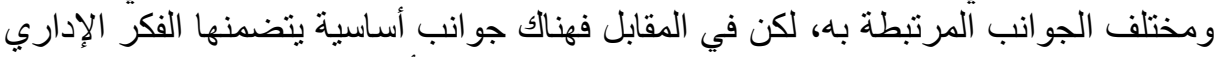

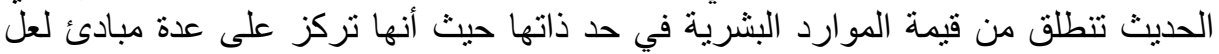

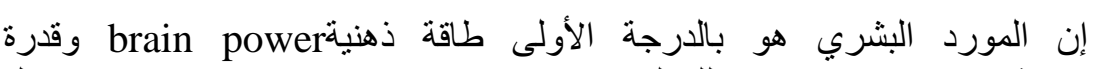
أبرز ها:

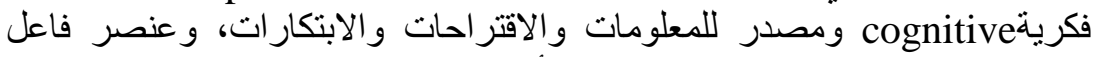
وقادر على المشاركة الايجابية بالفكر و الر أبي.

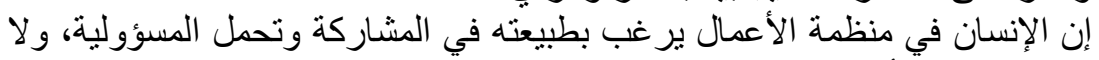

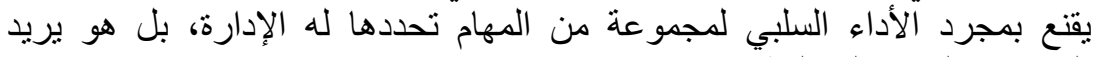

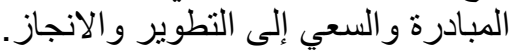

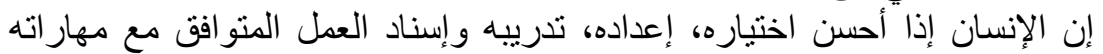

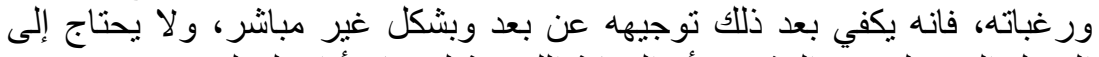

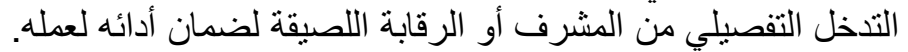

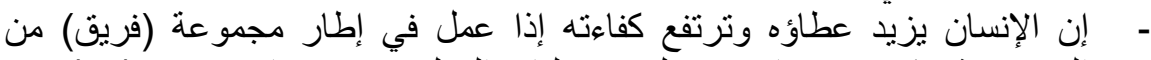

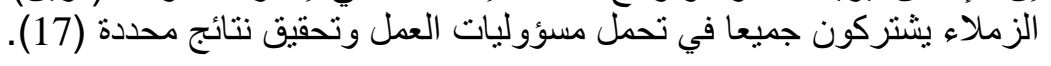




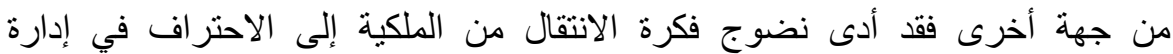

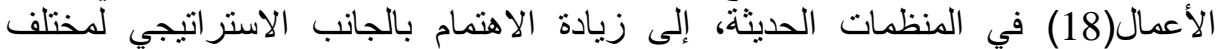

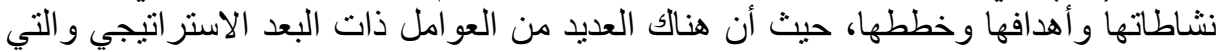

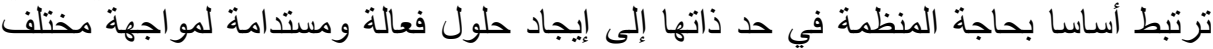

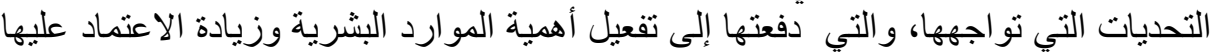

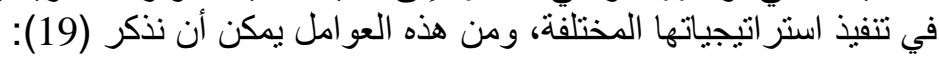

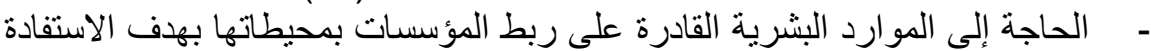

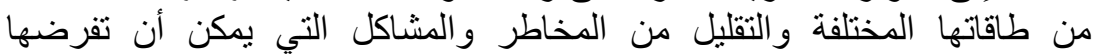
المحيطات، وخاصة الخارجية منها على المؤسسات. مو اكبة ومواجهة التطورات التشريعية/ القانونية و الاجتماعية و الاقتصادية و السياسية

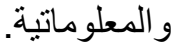
الحاجة إلى ربط أهداف الأفراد بأهداف المؤسسات، وذللك من خلال فهم واستيعاب

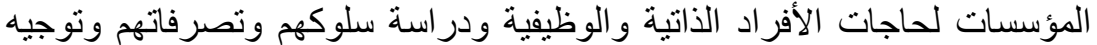

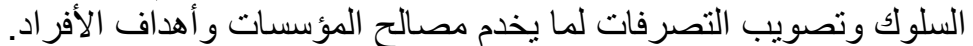

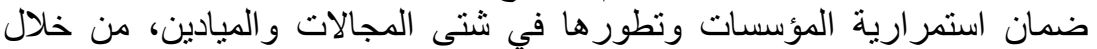

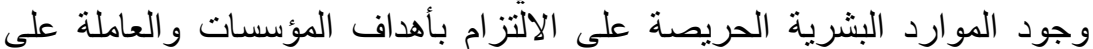
تحقبقها.

إن تجسيد هذه المقاربة المرتكزة على أهمية الموارد البشرية في بناء القدرات التنافسية

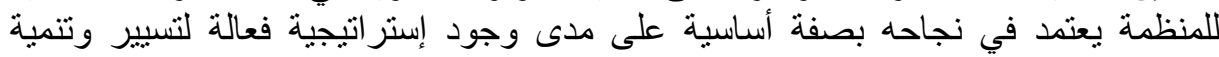

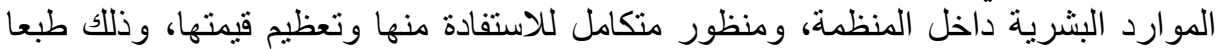

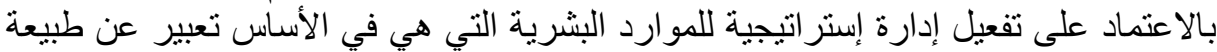

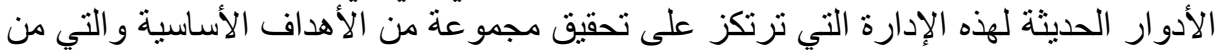

- - تحقيق تكيف نظام الموارد البشرية مع متغيرات البيئة التنافسية.

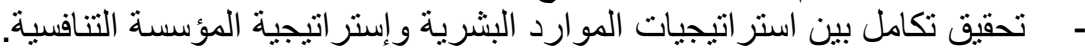

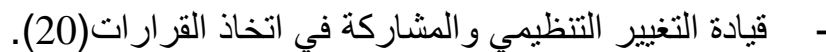

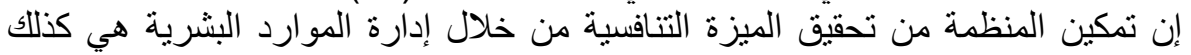

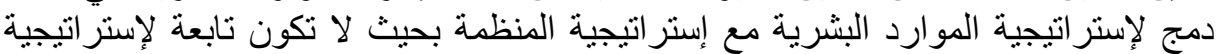

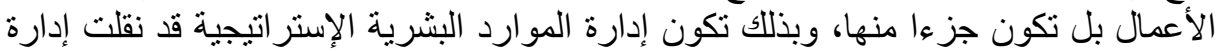

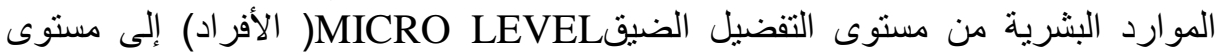
كليMACRO( إستر اتيجية الأعمال) (21).

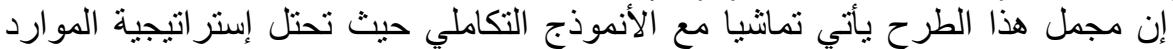

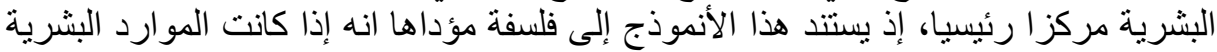

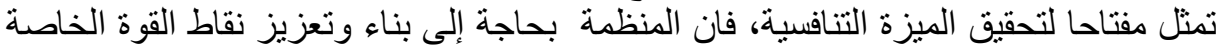

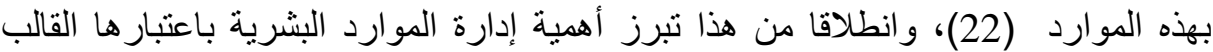

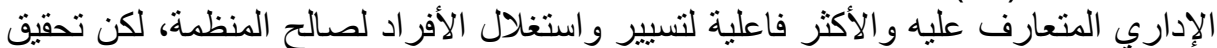

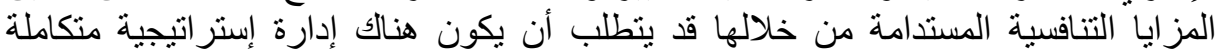

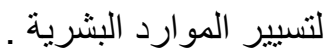

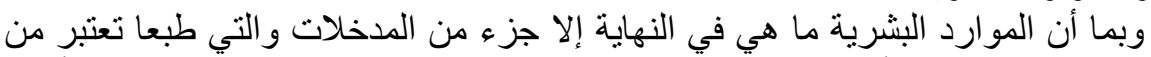

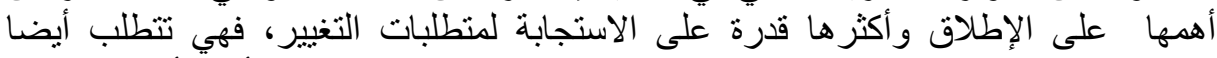

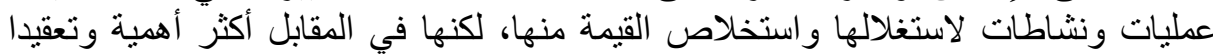

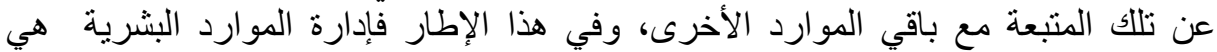

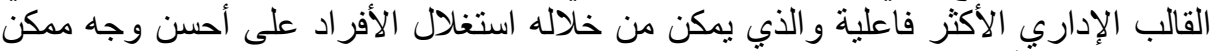

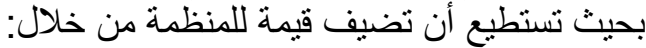

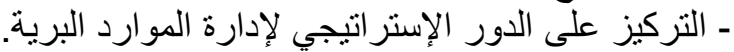

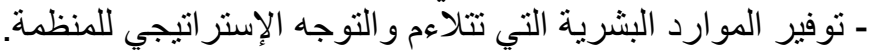

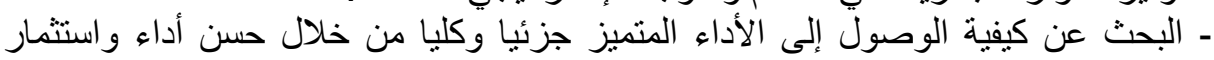
الموارد البشرية استثمار ا فاعلا لتحقيق نتائج ملموسة. الأنئ. 
التركيز على إحداث التغيير الإيجابي في المنظمة (23)

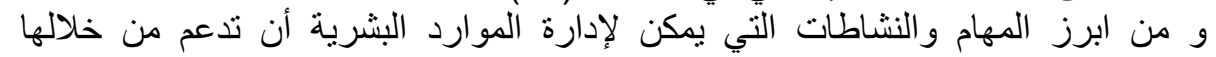

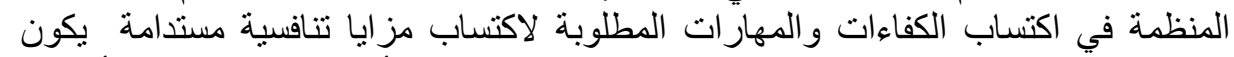

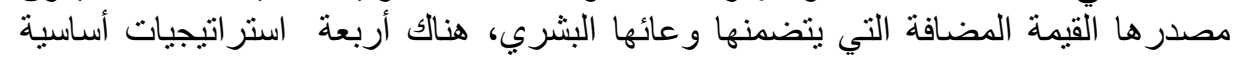
تتمحور حولها و تدعمها مجموعة من المهام و الوظائف الأخرى، و هذه الاستر اتيجيات تنمثل التئل

- - إستر اتيجية التدريب و التطوير بمختلف أنثكاله و أبعاده الحديثة

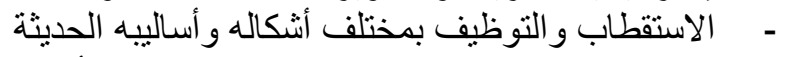

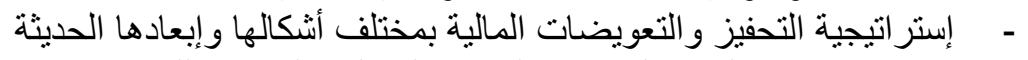

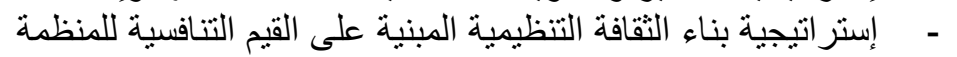

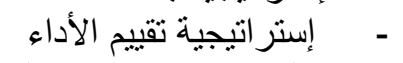

إذن فالدور الاستراتيجي الحديث الإداء الإدارة الموارد البشرية في تفعيل القدرات التنافسية

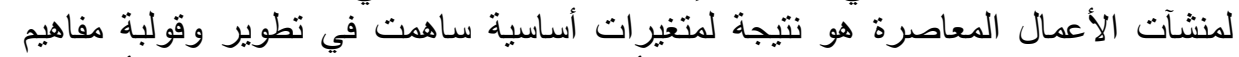

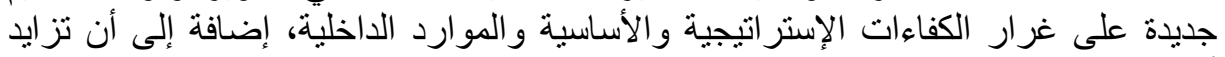

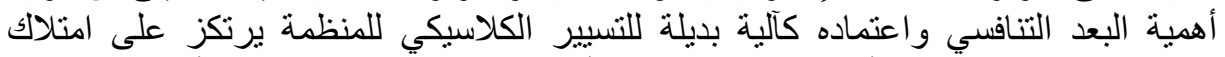

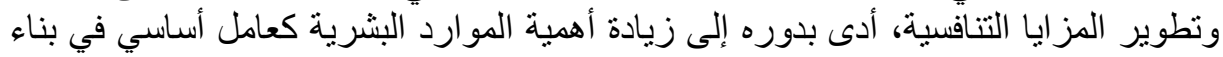

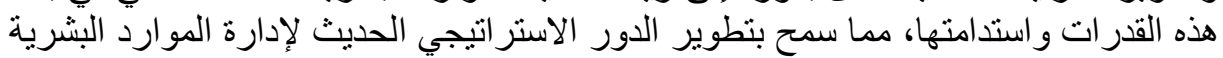

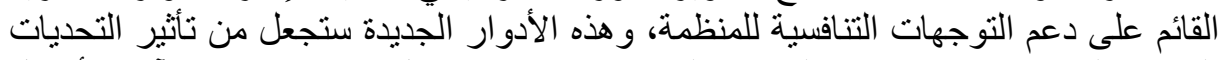

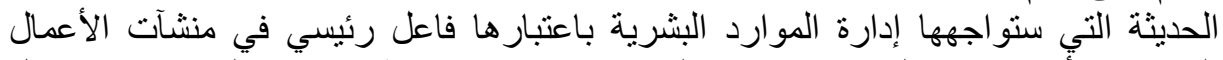

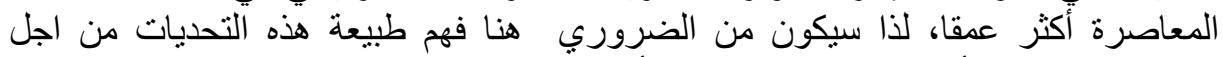

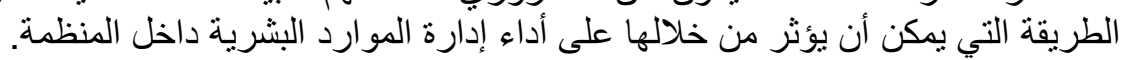

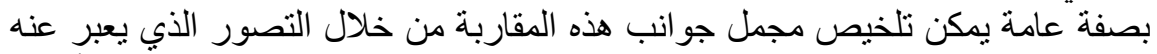

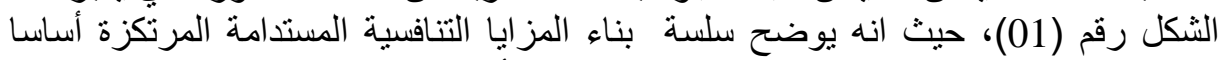

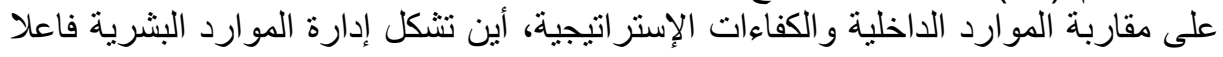

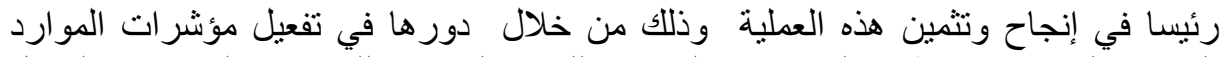

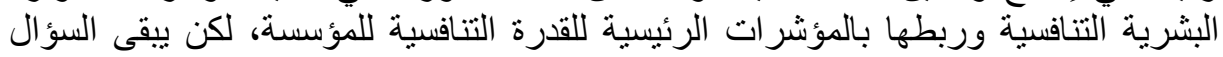

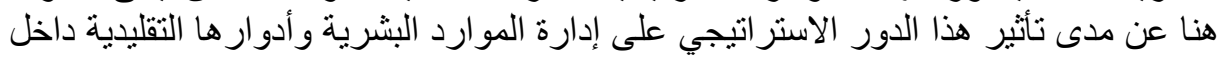

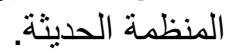

\section{2- إدارة الموارد البشرية وتحديات الدور الاستراتيجى الحديث:}

إن إدارة الموارد البشرية نواجه اليوم أكثر من أي وقت مضى تحديات كبيرة ومتعددة

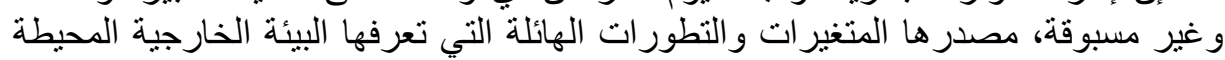

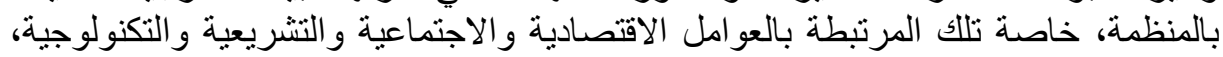

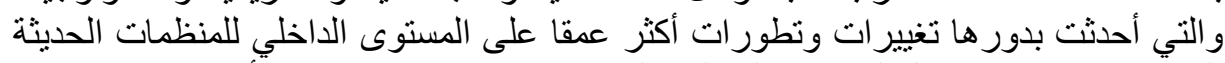

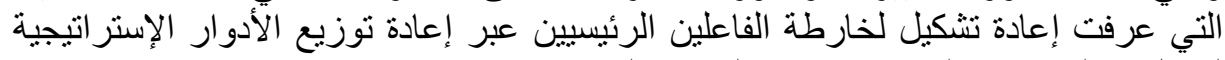

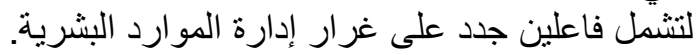

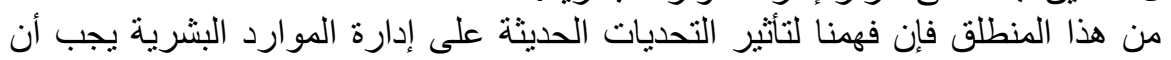

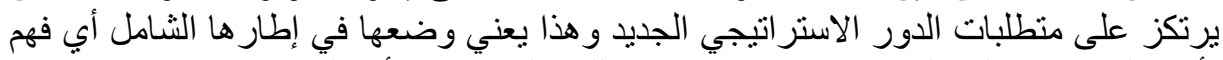

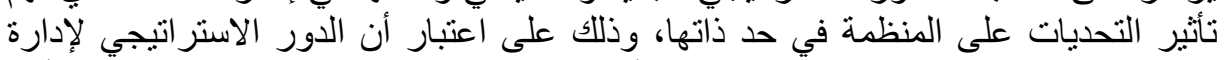

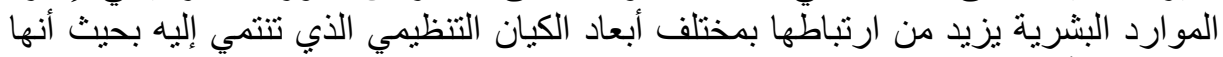

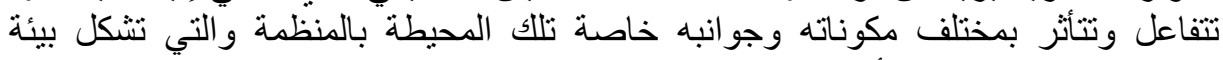

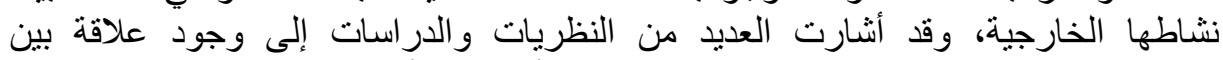

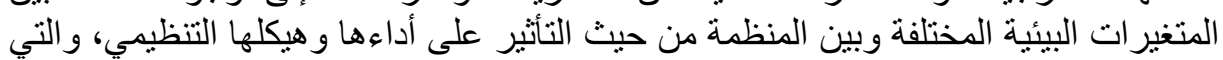

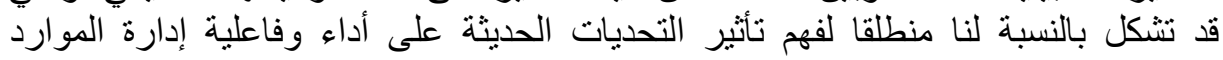
البشرية وبنيتها الهيكلية.

في دراسة لـ"شاندلز" ترنكز على أساس النتائج التي حصل عليها (1962) من مر اجعة 
نمو وتطور حوالي 100 شركة أميركية كبيرة استنتج أن كل تغيير رئيسي في تنظيم هذه النيا

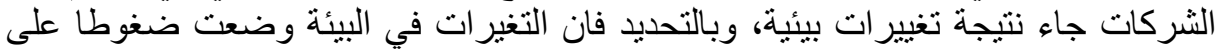

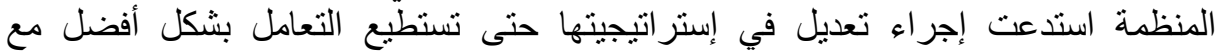

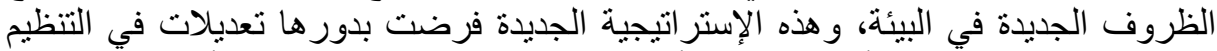

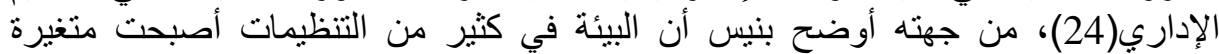

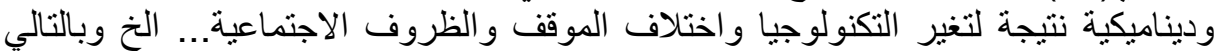

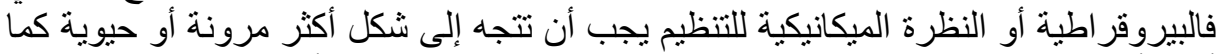

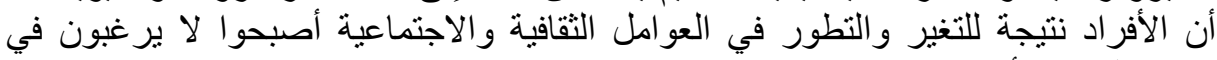

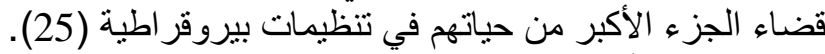

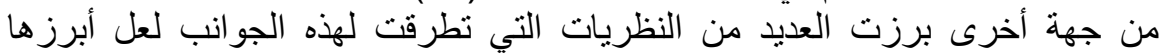

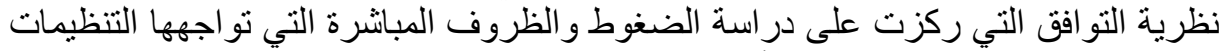

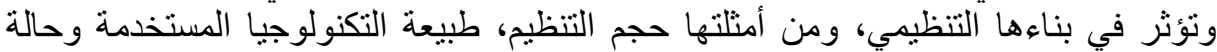

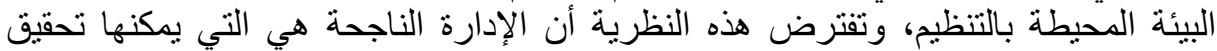

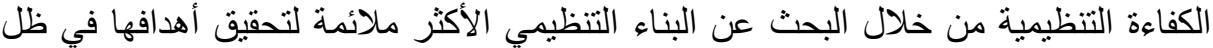

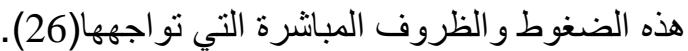

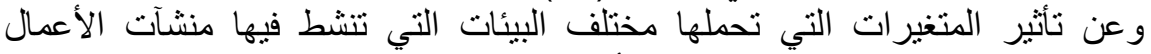

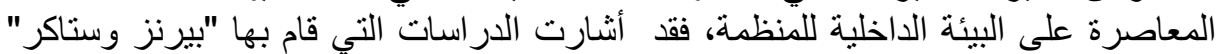
إلى طبيعة الهياكل التنظيمية التي ينبغي على المنظمات أن تعتمدها في ظل الظئل الظروف البياتئية

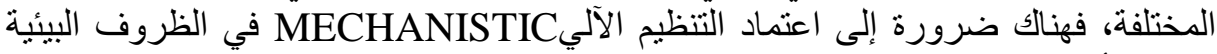

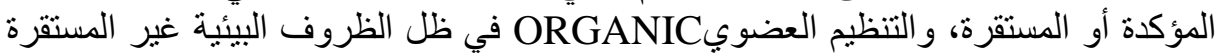

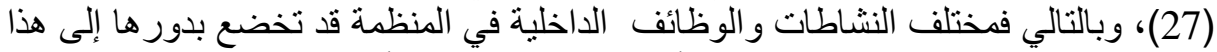

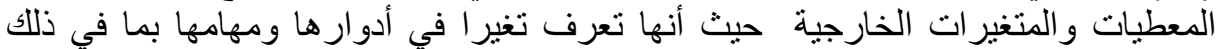

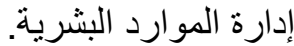

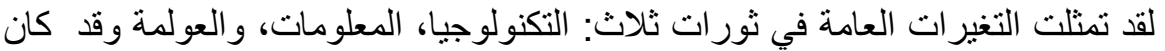

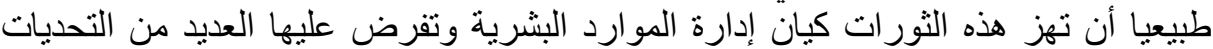

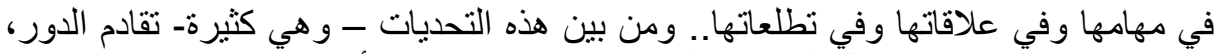

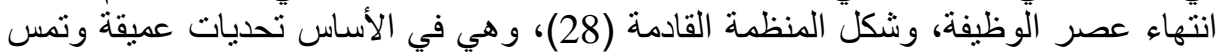

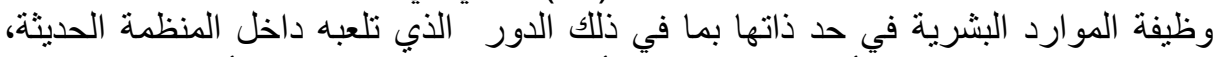

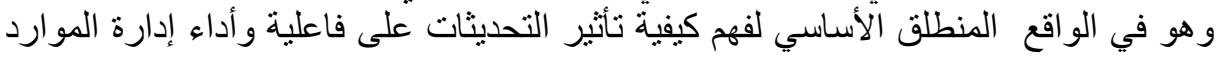

في الواقع هناك العديد من التحديات الحديثة التي تواجهها إدارة الموارد البشرية داخل البشرية البية

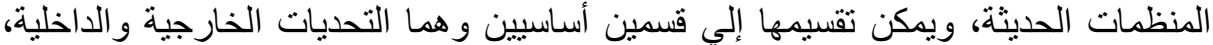

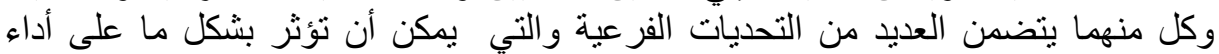

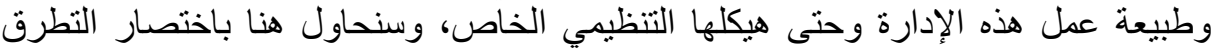

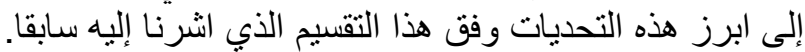

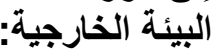

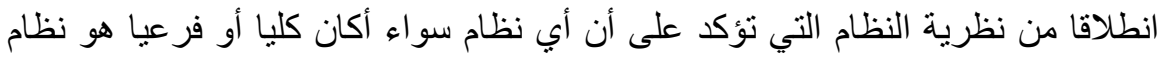

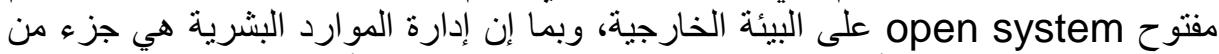

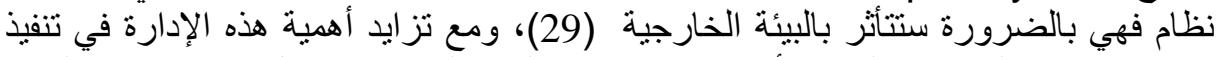

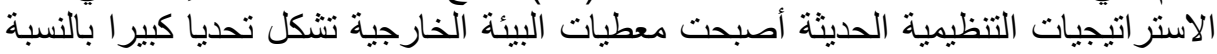

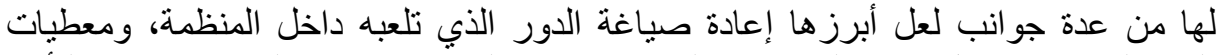

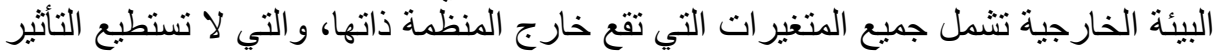

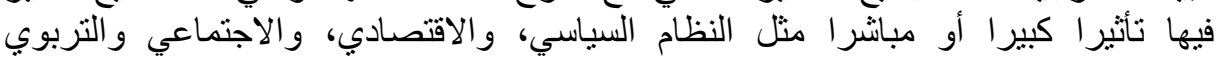

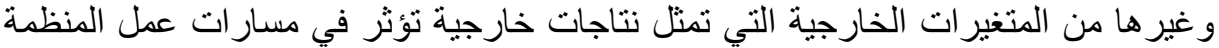

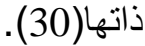

و في المقابل ومن منطلق التحليل التنظيمي الكلاسيكي للبيئة الخارجية لنشاط المنظمة ، فهي التئي

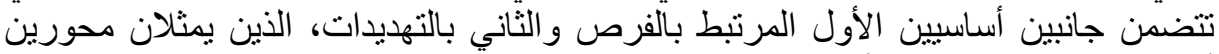

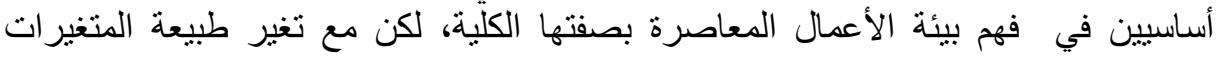


الخارجية وتزايد وتيرتها أصبح هناك تحدي آخر تواجهه إدارة الموارد البشرية من البيئة

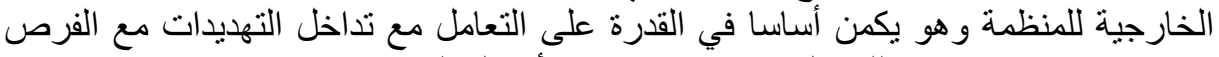

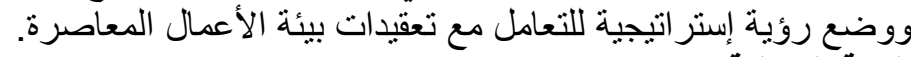

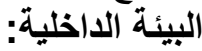

غالبا ما ينظر للبيئة الداخلية للمنظمة أنها الأكثر استقرارا ووضوحا عن البيئة البها لئنة

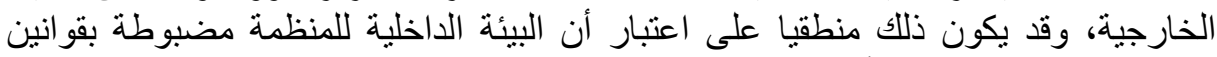

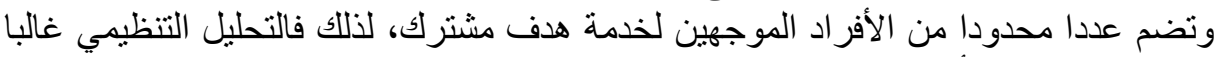

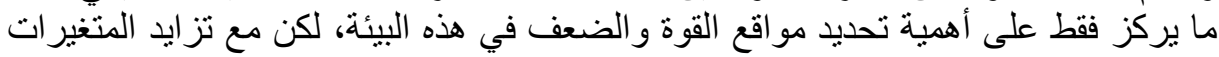

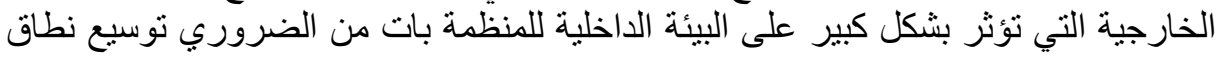

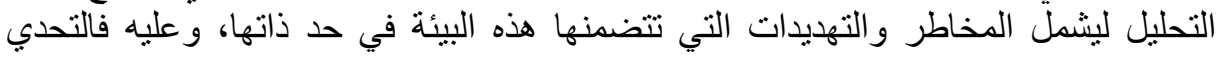

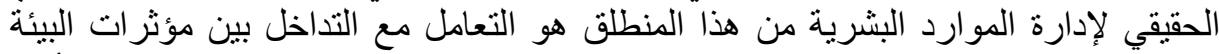

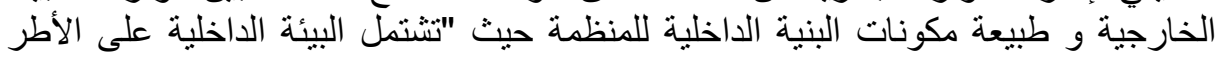

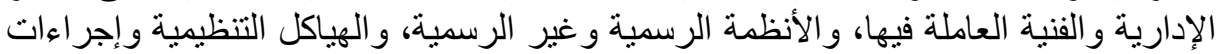

وسياقات تنفيذها، والتكنولوجيا التئة المستخدمة (31)

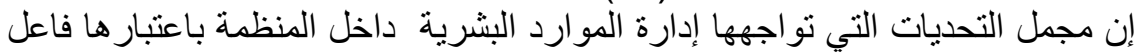

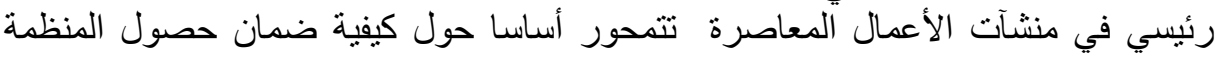

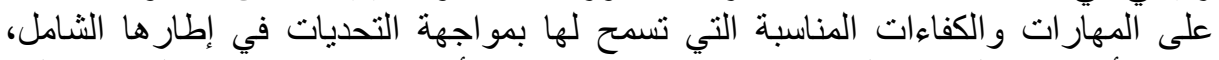

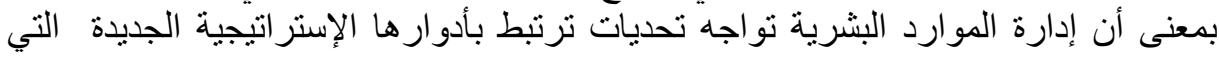

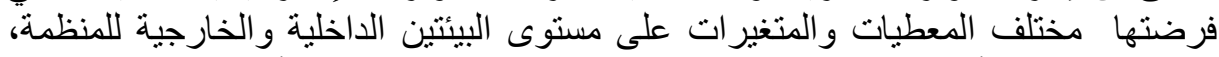
ولعل من ابرز الأدوار التي تفرضها التحديات الحديثة على منشآت الأعمال الحديثة مايلي:

$$
\text { - - مإعادة النظر في نماذج القيادة: }
$$

تحمل مواضيع القيادة أهمبة محورية في المؤسية الحئية الحيثة، فعلى إدارة الموارد البشرية

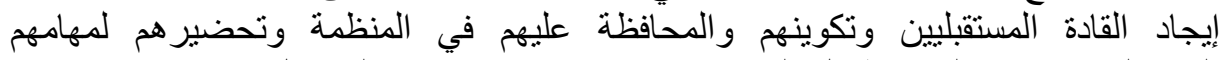

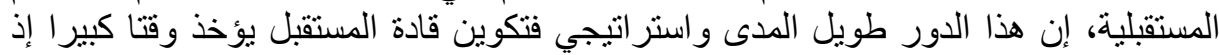

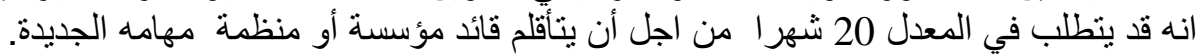

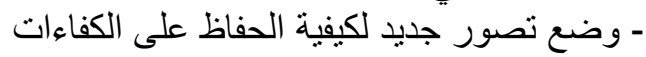

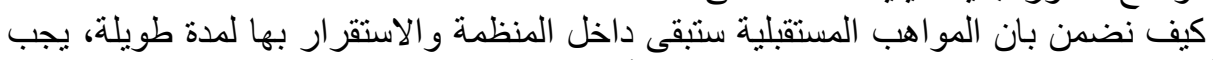

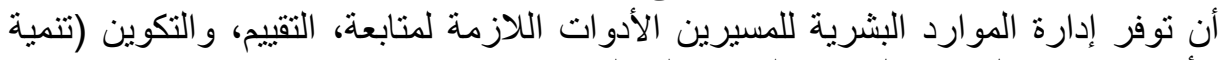

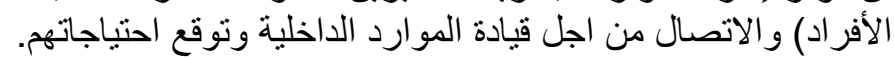

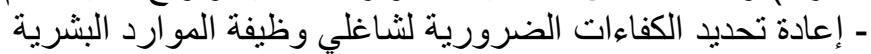

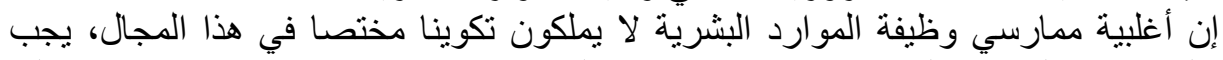

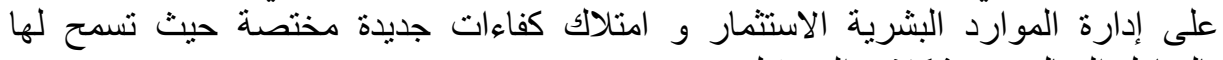
بالتعامل الفعال مع مشكلات المستقبل.

إذن فهذه المعطيات تشير إلى أن إدارة الموارد البشرية الحديثة يتوقع منها أداء ادوار

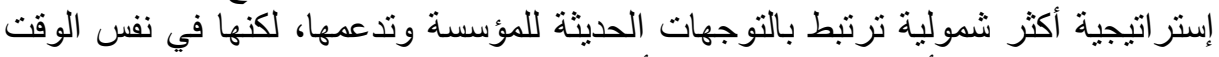

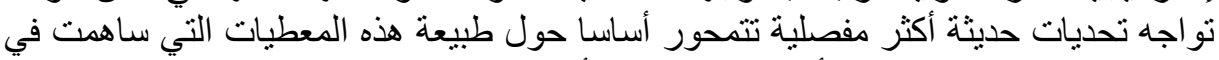

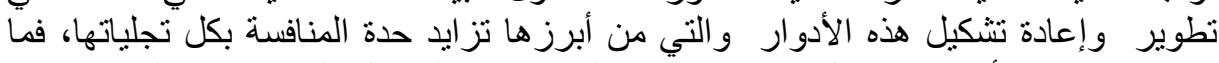

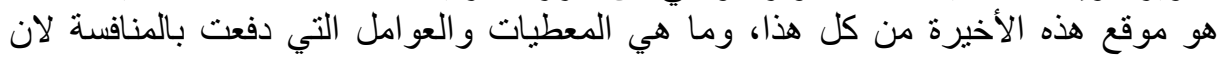
تكون واجهت الإستر اتيجية الجديدة بالنسبة للمؤسسة الحديثة.

\section{- V}

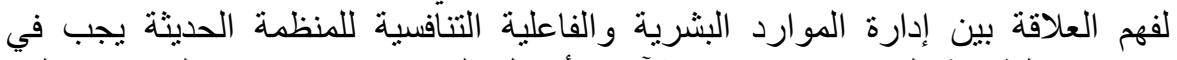

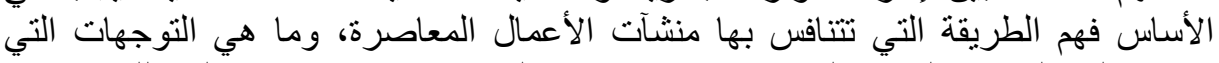

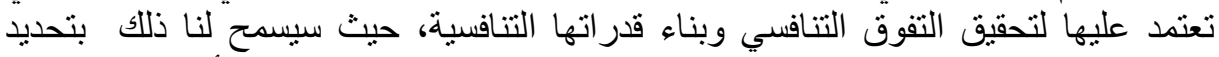
مكانة إدارة الموارد البشرية في كلّ إستراتيجية انطلافا من المقاربات والأسس التي تعتمد 
عليها، وفي الواقع فهذه العلاقة تعتبر جزءا من خصائص ومميزات الأدوار الحديثة لإدارة

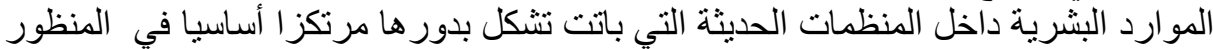

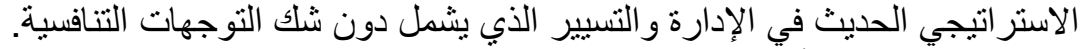

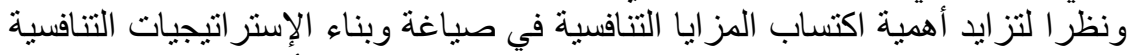

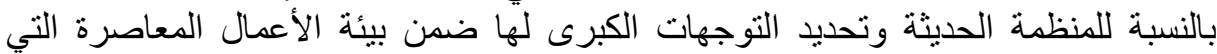

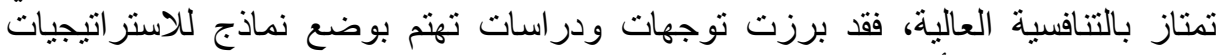

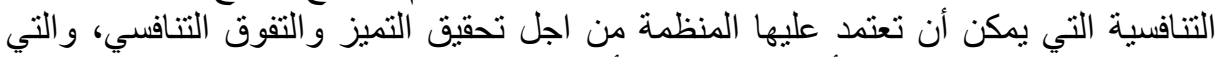

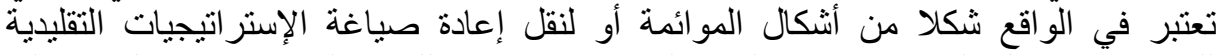

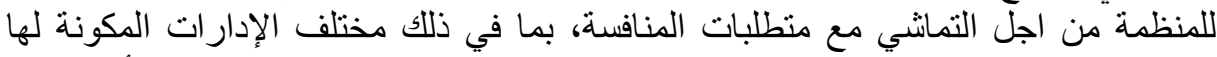

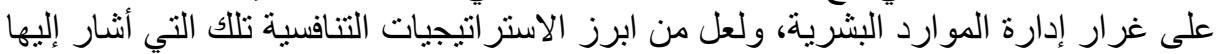

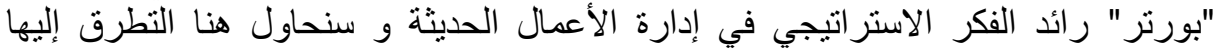

$$
\text { وربطها بمختلف ادوار إدارة الموارد البشرية. }
$$

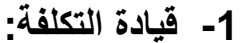

تعتبر قيادة التكلفة من ابسط الاستراتيجيات التنافسية فمن خلال تحقيق اقل تكلفة للإنتاج

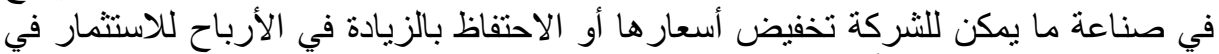

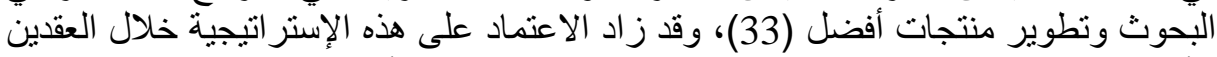

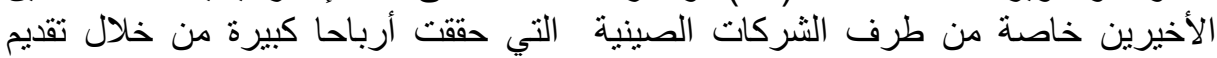

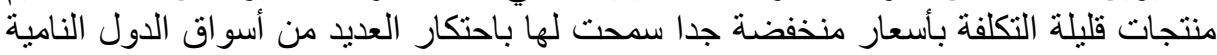

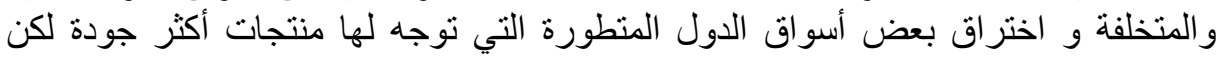
بتكلفة اقل تسمح لها بمنافسة منتجات المؤس الستسات الكبيرة.

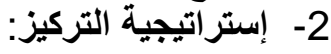

تركز الثركة باستخدام هذه الإستراتيجية على سوق أو شريحة سوقية معينة أو منتج

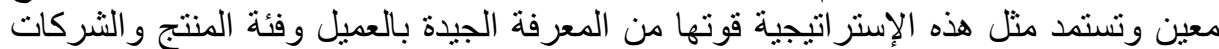

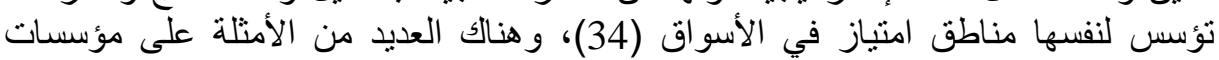

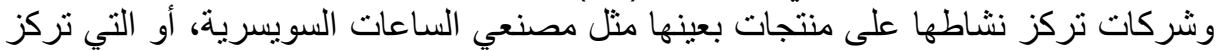

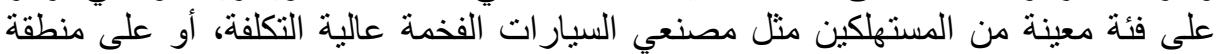

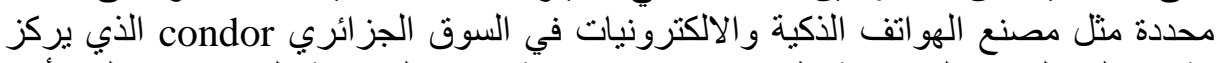

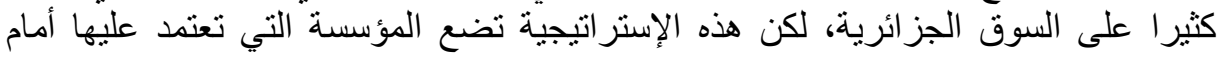

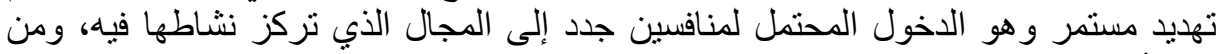

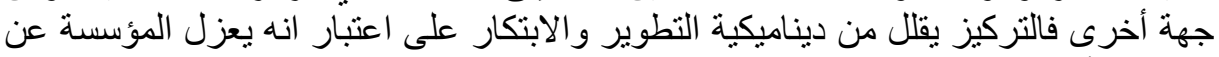
النطاق الأوسع للمنافسة.

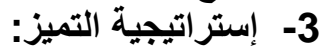

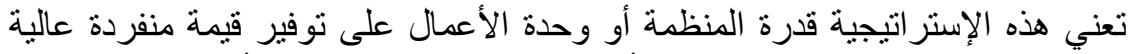

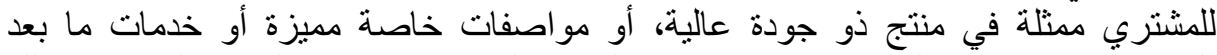

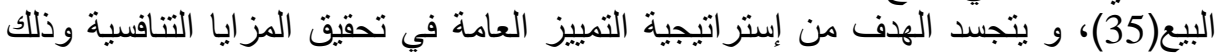

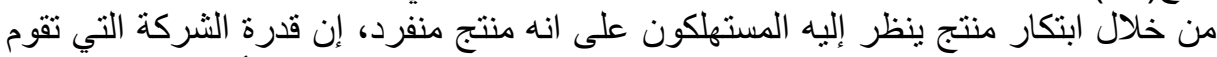

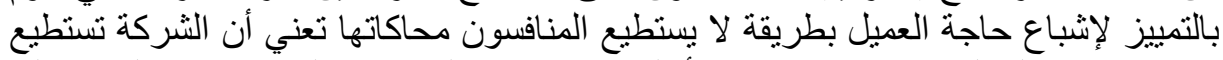

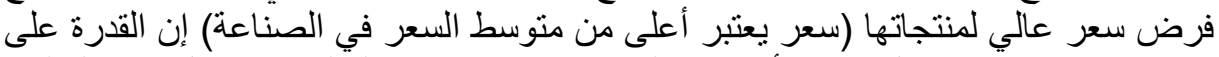

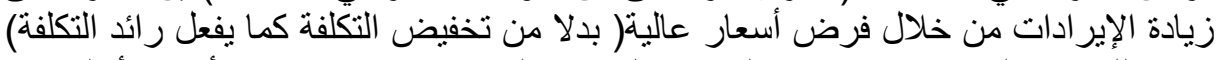

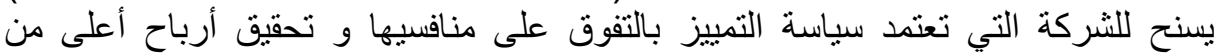

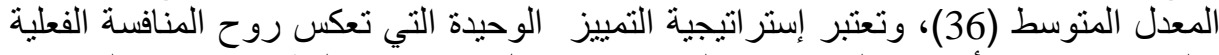

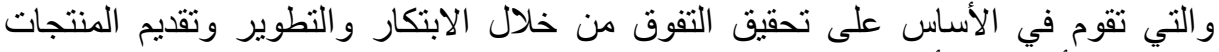
الخدمات الأحسن و الأكثر جودة. إن تطرقنا للاستراتيجيات التنافسية يهدف في الأنيات الأساس إلى تحديد أهم مؤشرات القدرات

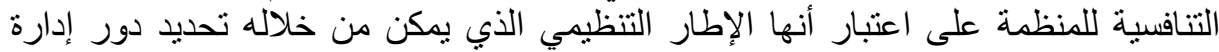

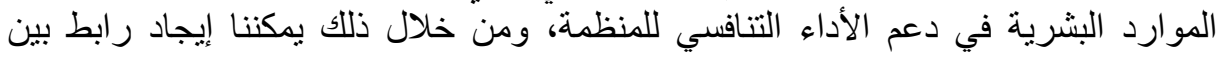

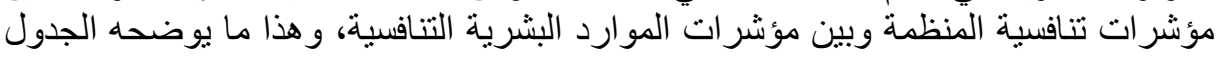

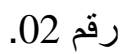


إن مختلف الاستر اتيجيات التنافسية ترنكز على مقاربات مختلفة لكنها تتقاطع جميعا

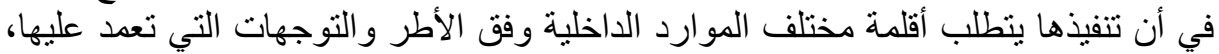

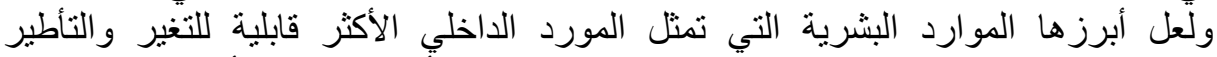

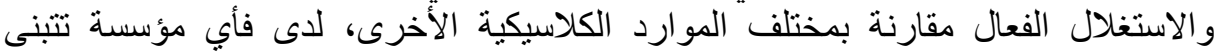

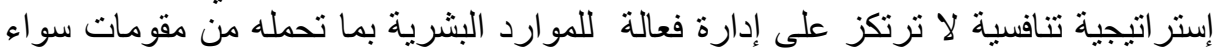

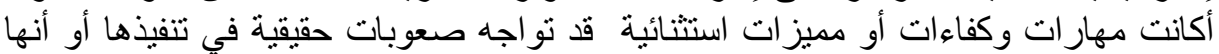

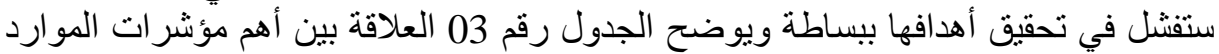

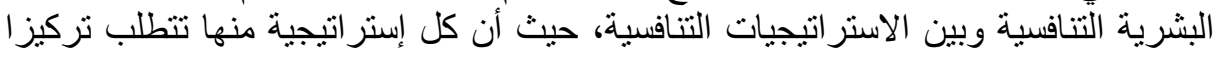

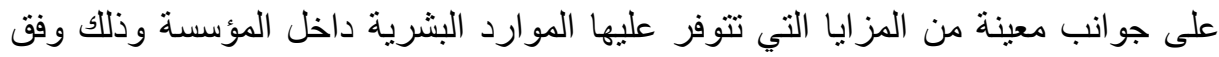
المنظور الاستر اتيجي الحديث.

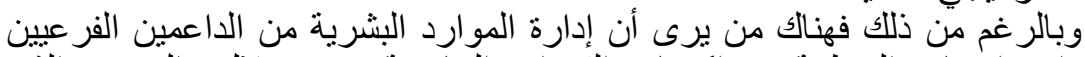

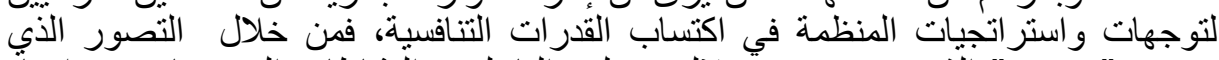

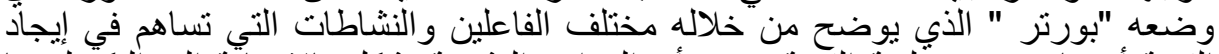

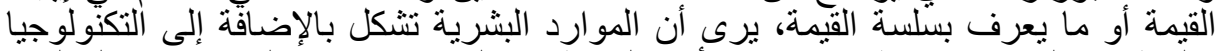

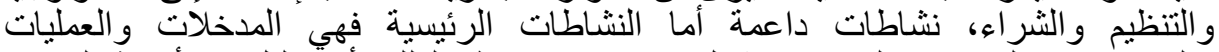

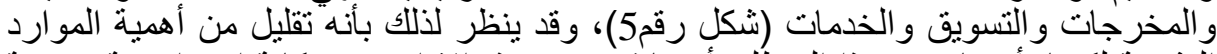

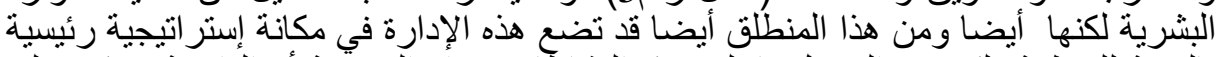

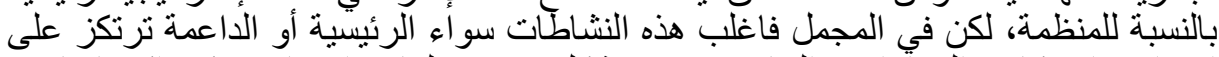

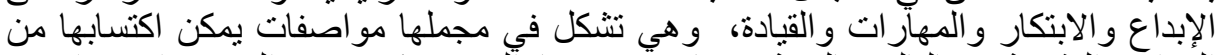

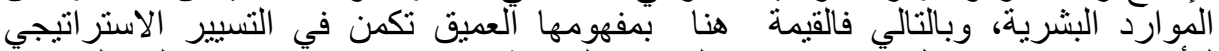

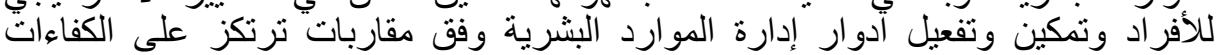

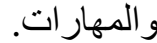

\section{- تأثير التحديات الحديثة لادارة الموارد البثرية على القدرة التنافية للمنظمة: VI}

إن المنافسة اليوم تعتبر المحرك الأساسي لمختلف نشاطات منشآت الأعمال

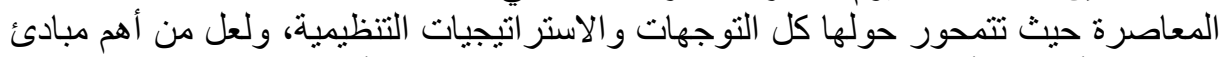

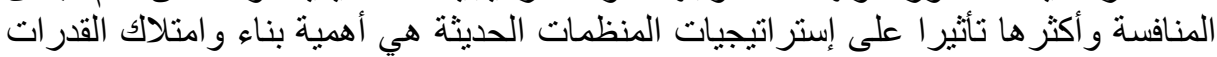

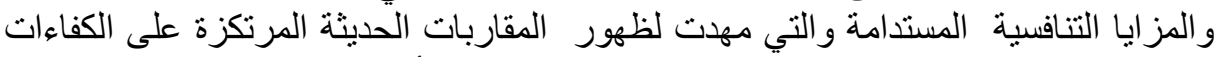

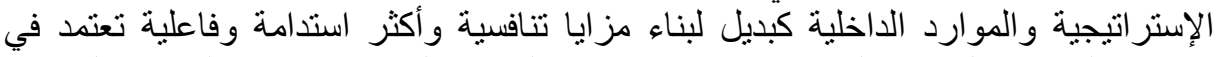

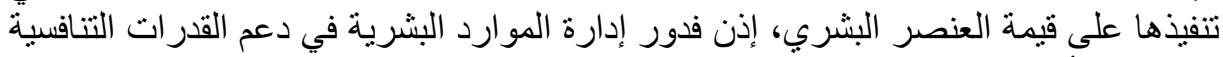

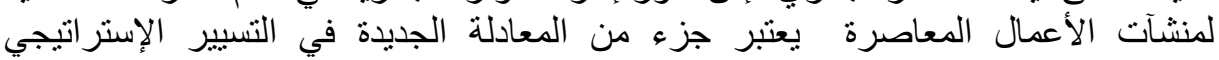

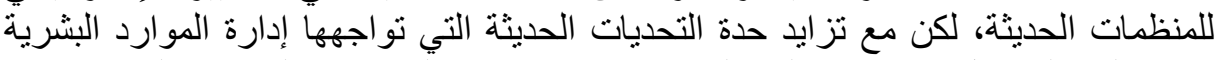

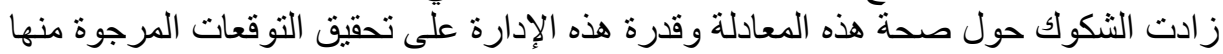

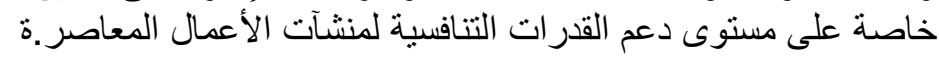

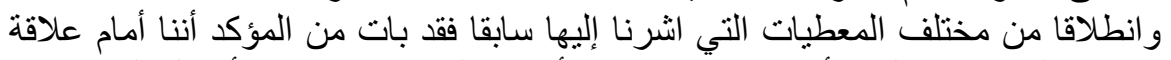

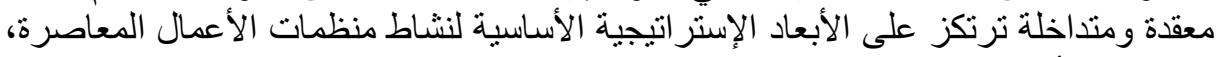

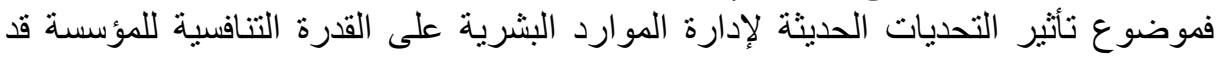

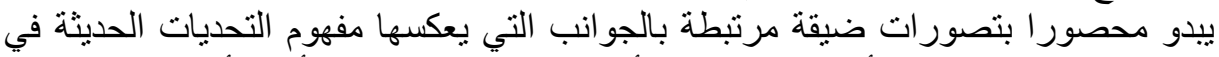

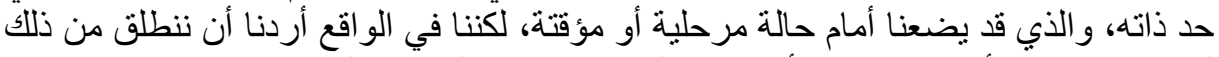

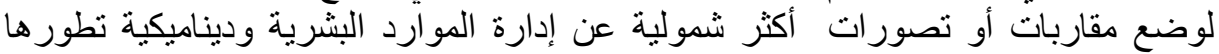

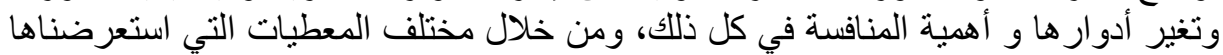

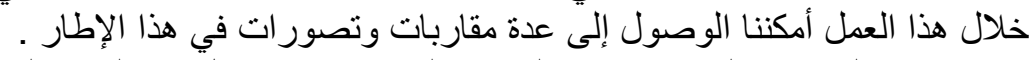

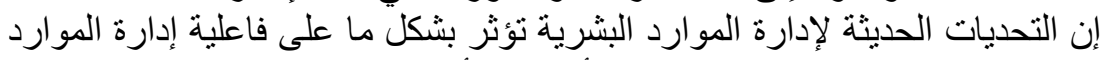

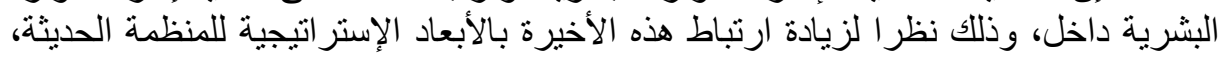

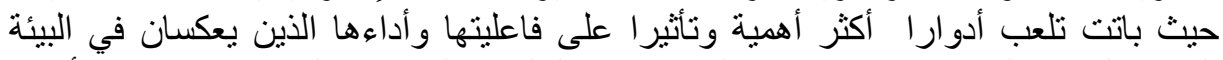

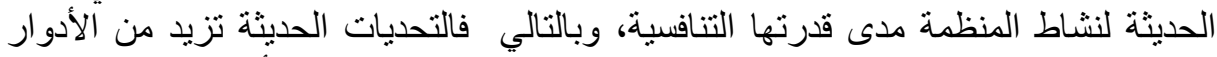

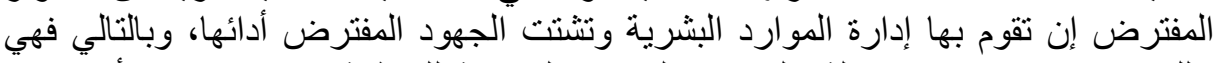

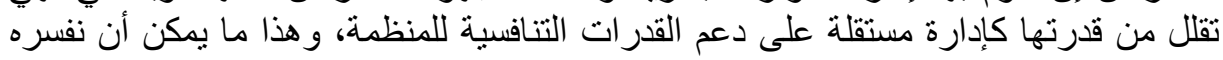


بوجود تناقض إلى حد ما بين ما يتوقعه مسؤولي المنظمة من هذه الوظيفة وبين درجة الأهمية

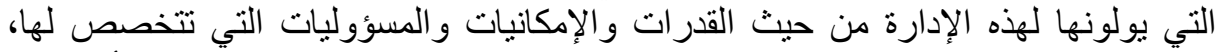

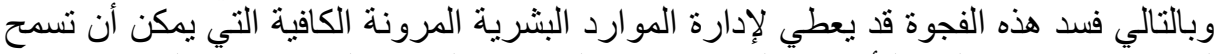

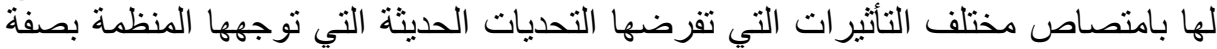
عامة.

إن هذه المقاربة تتطلب في الواقع مراجعات عميقة للنماذج السائدة لإدارة وتسيير

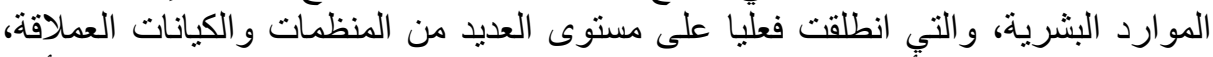

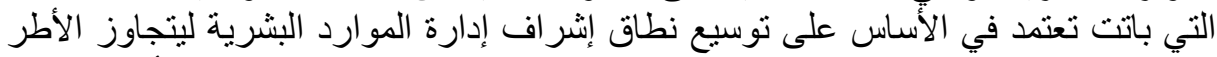

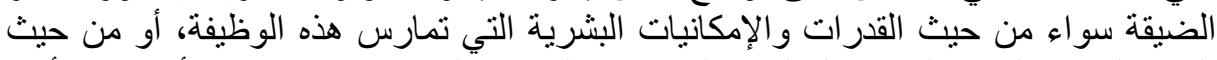

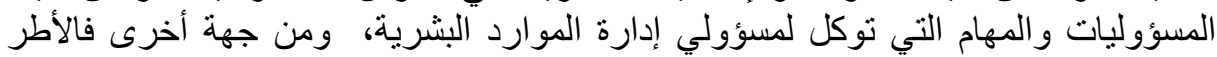

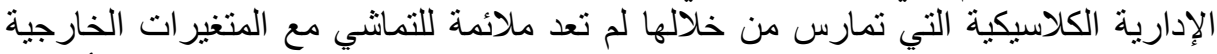

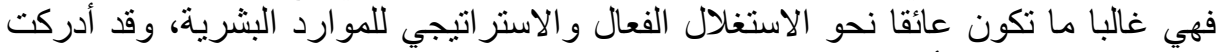

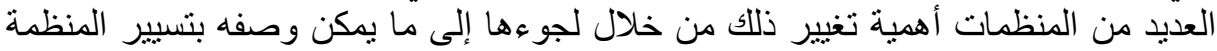
بالكامل بمنظور إدارة الموارد البشرية حيث يكون الفرد هو المحات المور الأساسي في عملية التسيير الثاملة.

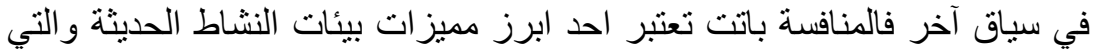

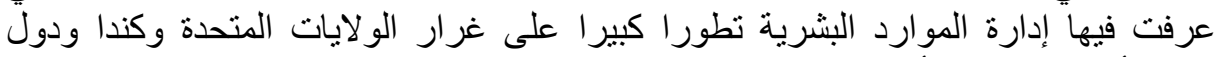

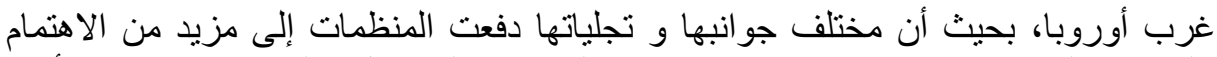

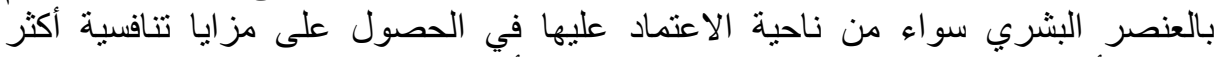

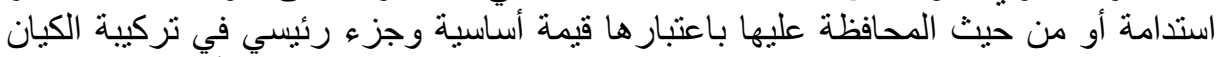

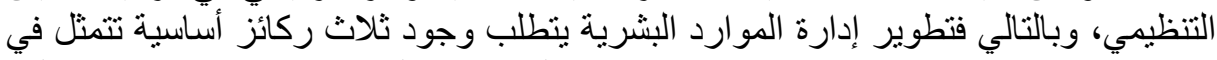

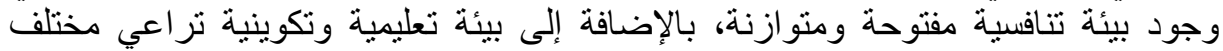

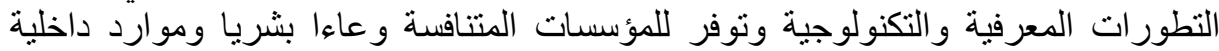

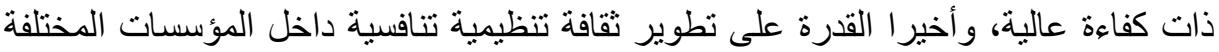

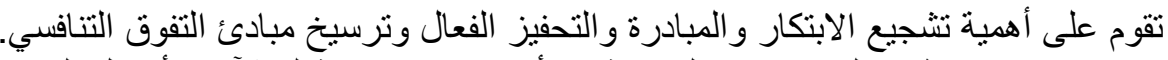

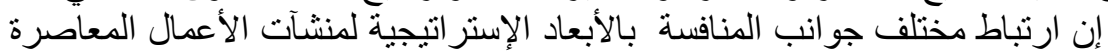

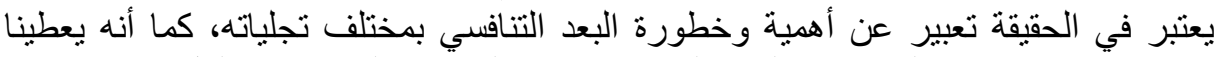

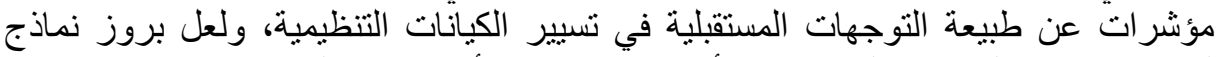

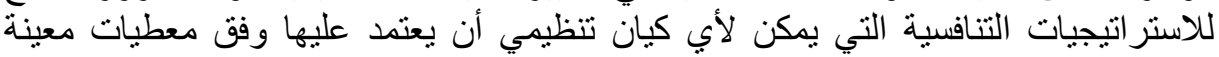

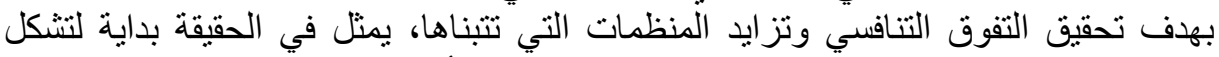

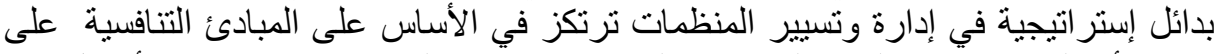

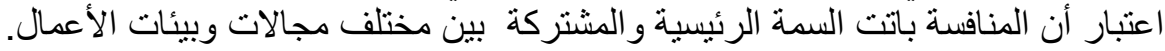

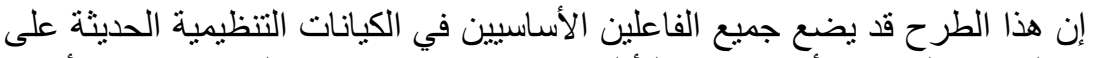

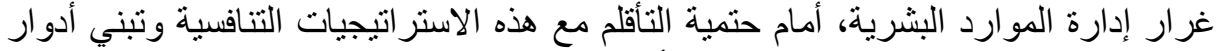

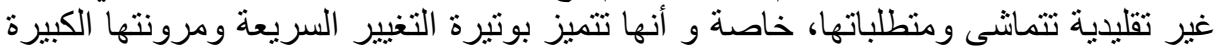

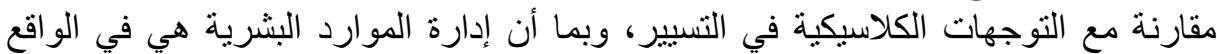

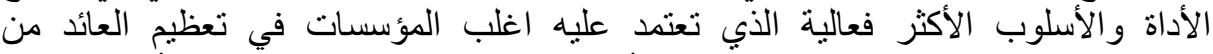

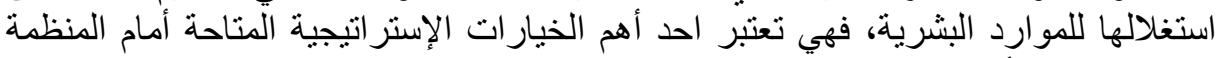

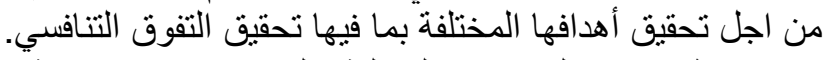

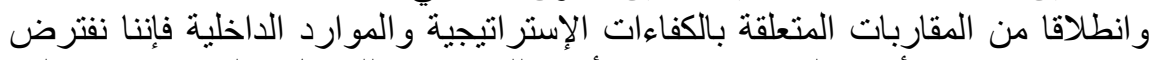

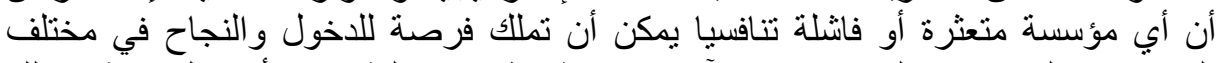

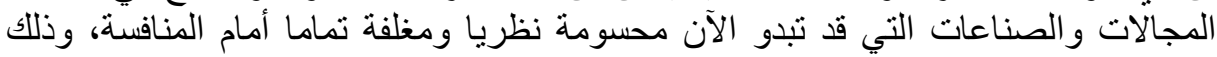
طبعا وفق التحليل المرنكز على تحليل هيكل الصناعة كمنطلق لفهم قدرات التئ المؤسسة التنافسية

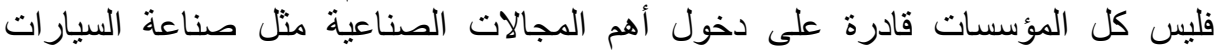

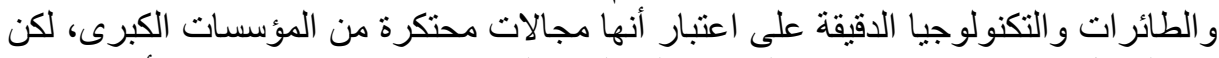

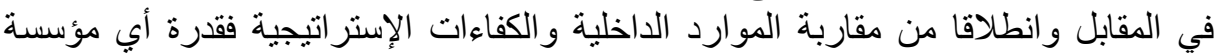

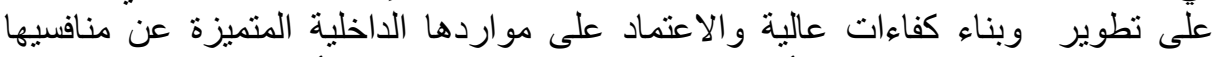

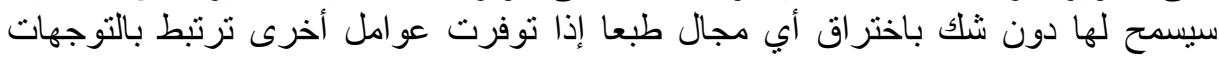


الاقتصادية للاولة و مدى نوفر البنية التحتية والدعم الكافي، وفي هذا الإطار فالنموذج التئ

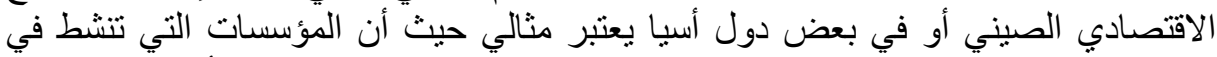

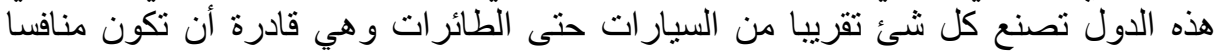

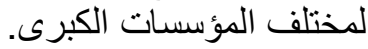

وبالر غم من أن هناك العديد من الباحثين و الأكاديميين المهتمين بشؤون تحسين وتطوير الإنير

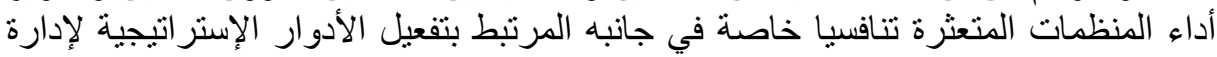

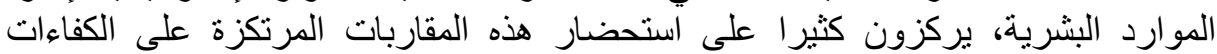

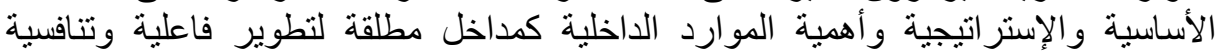

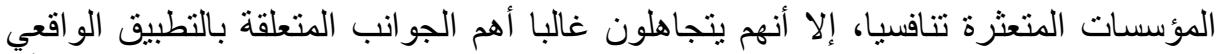

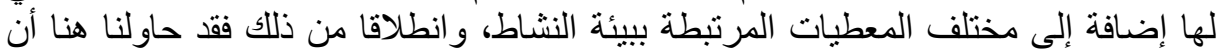

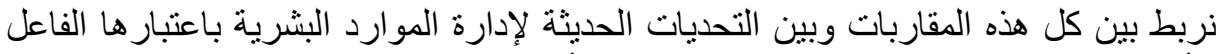

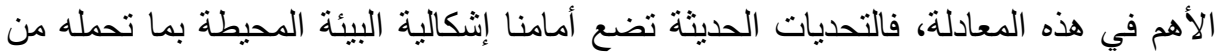

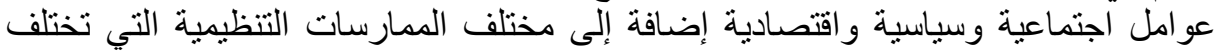

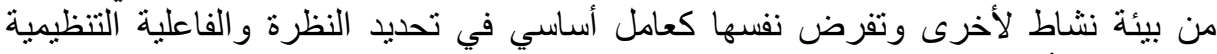

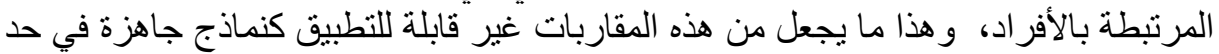

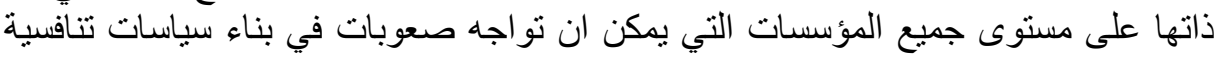

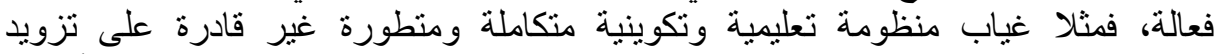

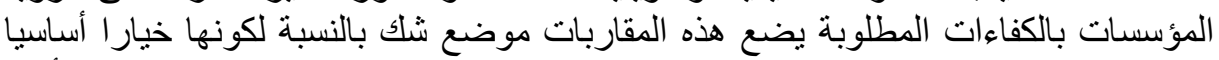

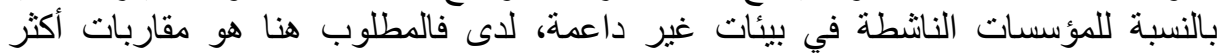

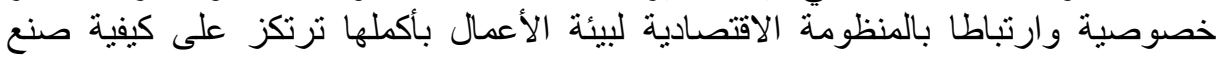

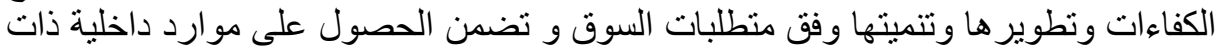

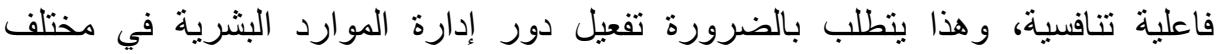
المستويات التنظيمية.

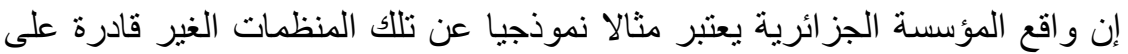

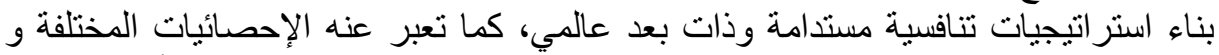

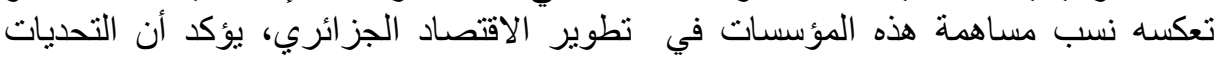

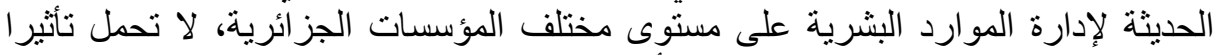

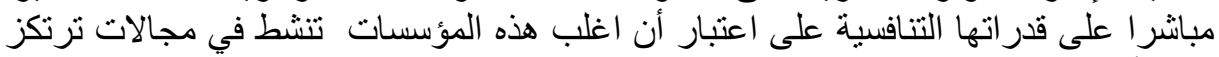

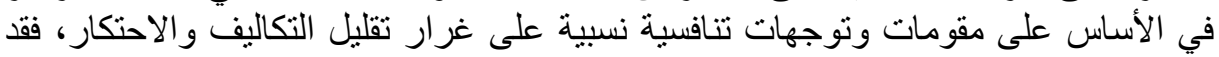

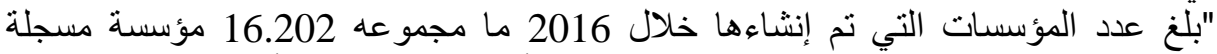
في السجل التجاري ....، وتم إنشاء هاته المؤسسات أساسا في قطاعات أنشال البناء البناء (1.544)

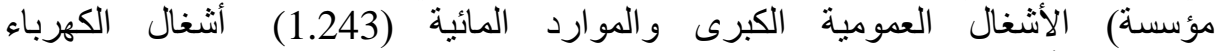

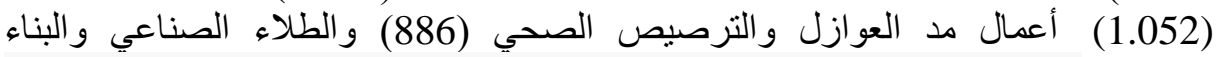

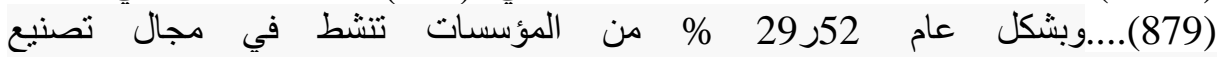

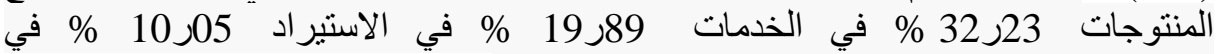

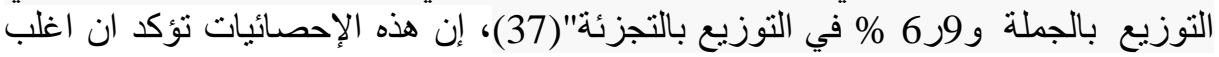

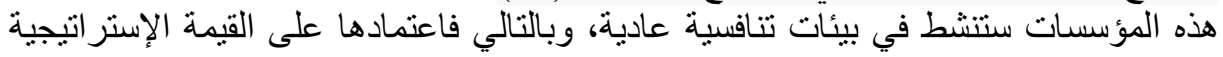

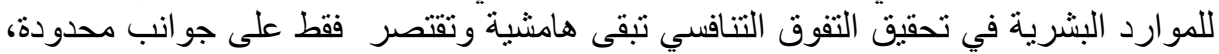

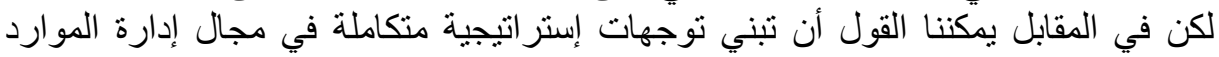

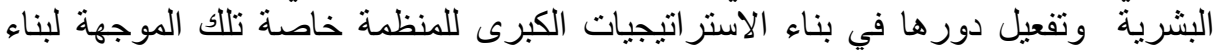

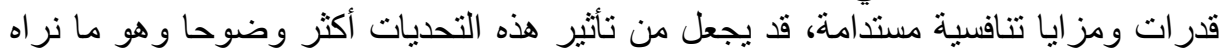

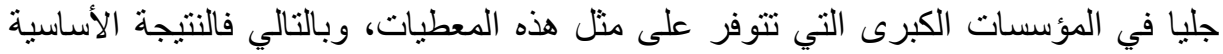

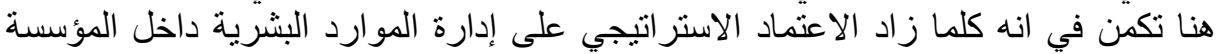

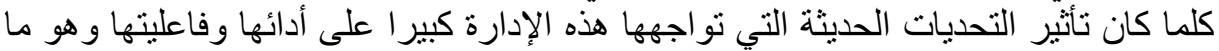

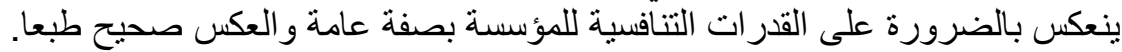

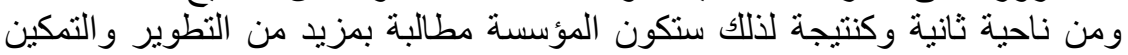
و التحسين لمختلف الجوانب المرتبطة بأداء وفاعلية إدارة الموارد البشرية من اجل البحنة المحافظة 


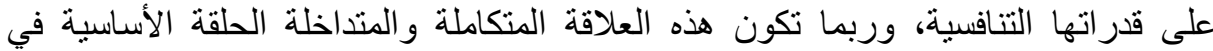

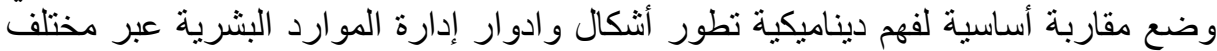

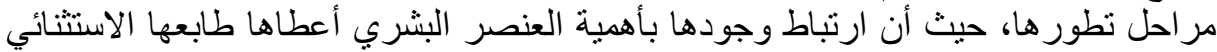

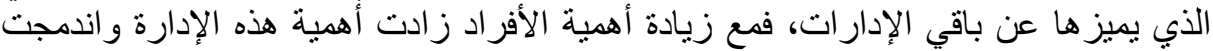

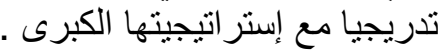

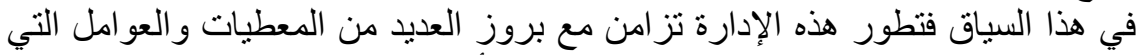

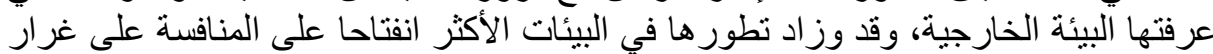

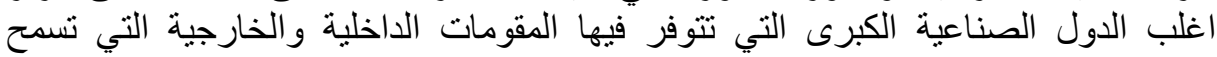

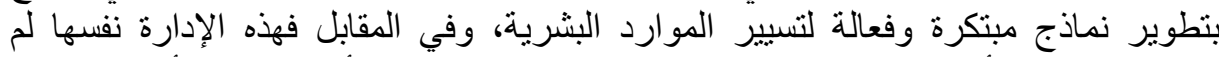

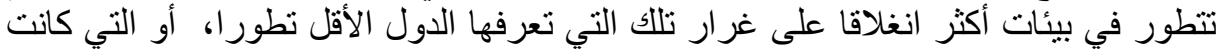

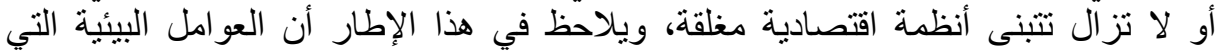

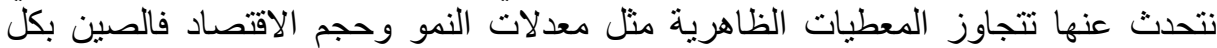

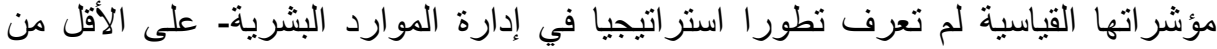

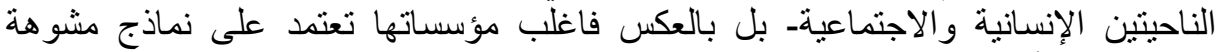

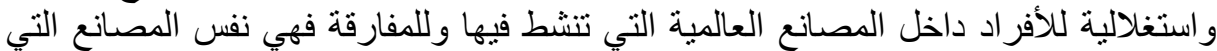

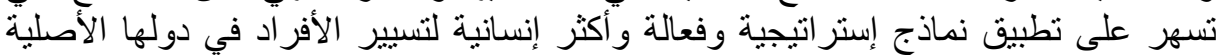

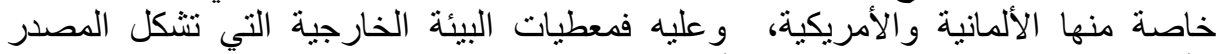

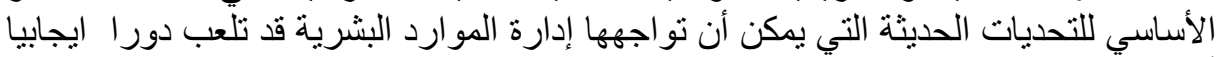

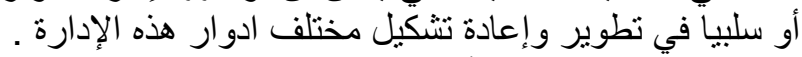

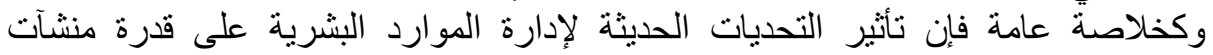

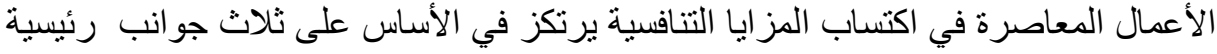
- مدى اعتماد المؤسسة على إدارة الموارد البشرية في تفعيل كفاءاتها الإستراتيجية و استغلال مو اردها الداخلية.

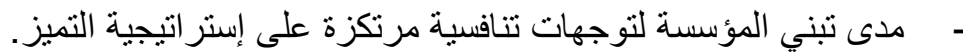

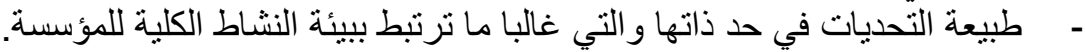
- مؤشرات البيئة التنافسية في المجالات الصناعية والخدماتية التي تنشط فيها

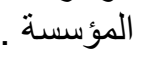

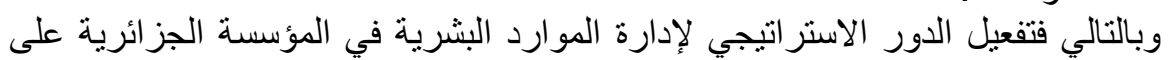
وجه الخصوص قد يتطلب وضع تصور الات جديدة كلبا ترنكز أو تنطلق من الإدارة النقاط الأساسية

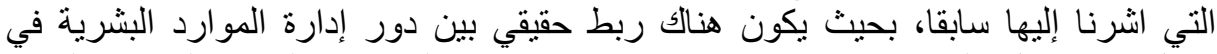

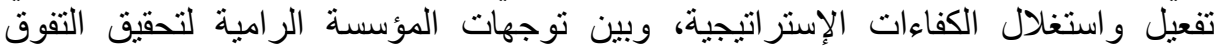

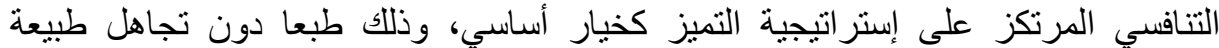

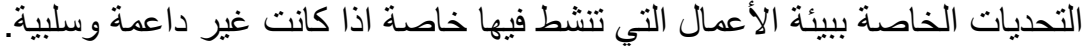
VII

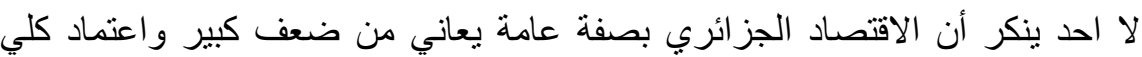

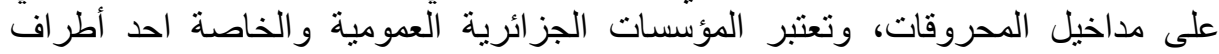

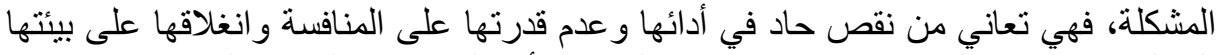

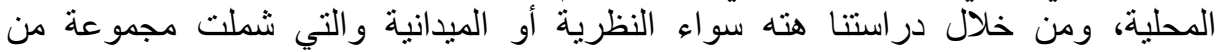

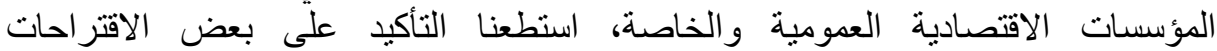
و التوصيات التي ربما تمت الإشارة إليها في دراسات سابقة عدئة التيدة ومنها:

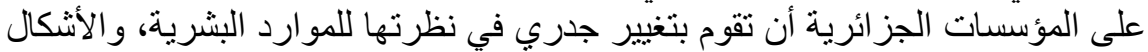

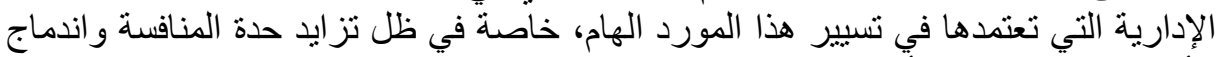

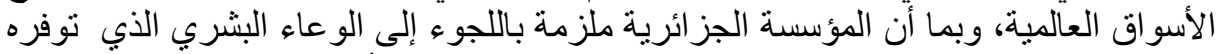

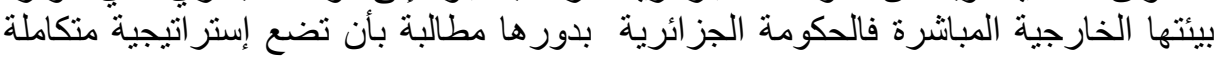

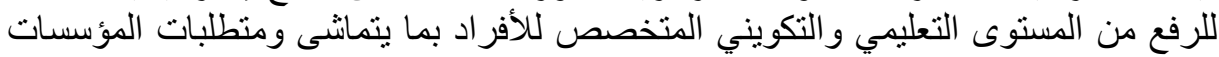
الاقتصادية المختلفة . فئري

في سياق آخر فقد نزايد الحديث مؤخرا عن أهمية جلب الاستثمارات الأجنبية إضافة 
إلى الضجة الكبيرة حول مصانع تركيب السيارات الأجنيية في الجزائر، وفي الواقع فهذه

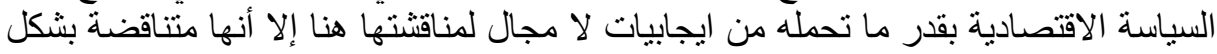

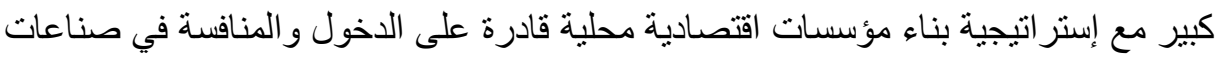

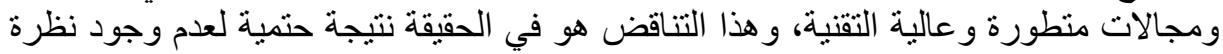

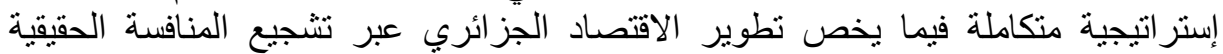

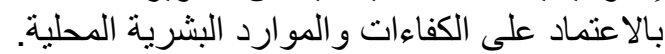

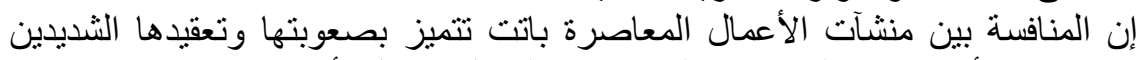

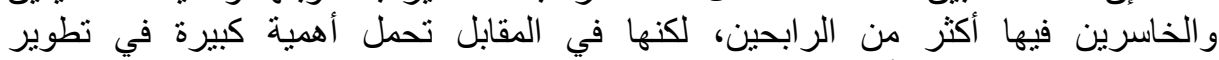

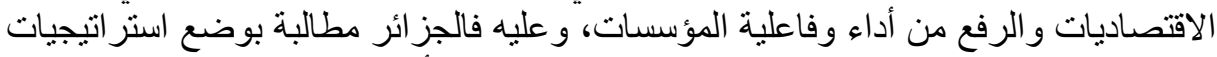

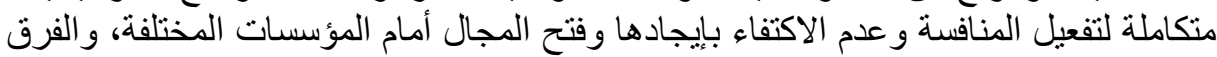

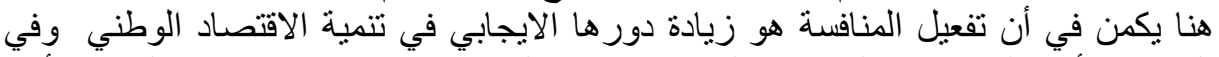

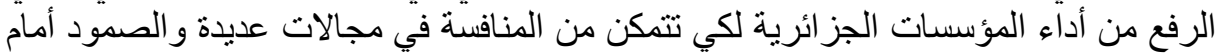
منافسة المؤسسات العالمية.

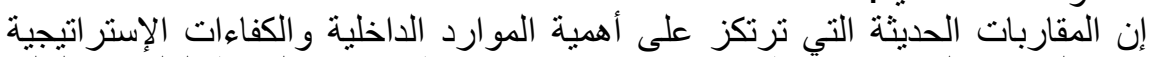

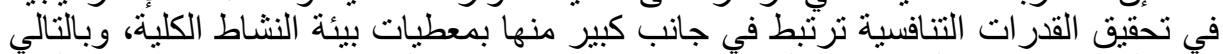

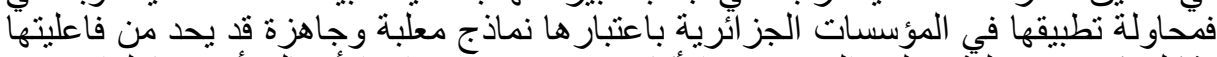

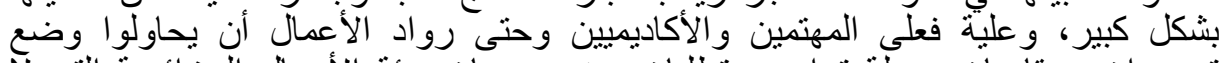

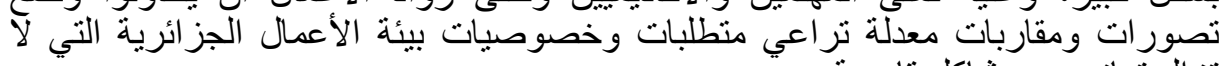
تزاتمة: تعاني من مشاكل قاعدية

لقد بات من الواضح أن التحديات الحديثة التي تواجهها إدارة الموارد البشرية قد تؤثر

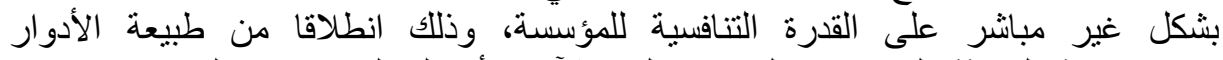

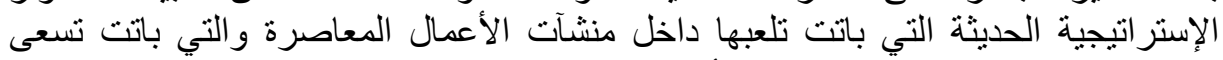

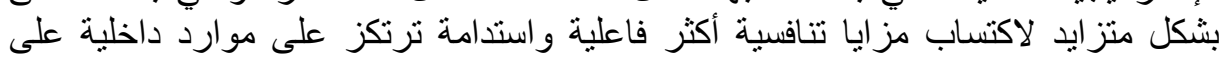
غر ار الموارد البشرية وذلك بالاعتماد طبعا على تفعيل الأدوار الإستر اتيجية لمختلفية فئلف الفاعلين

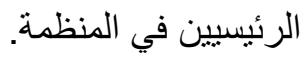

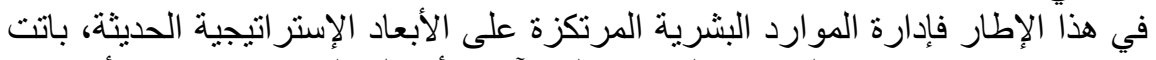

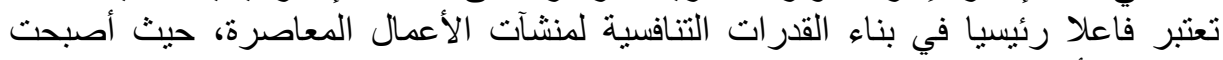

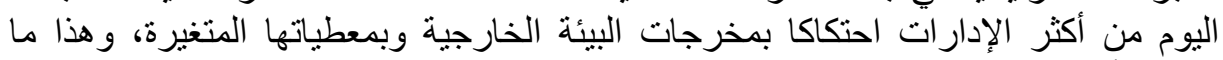

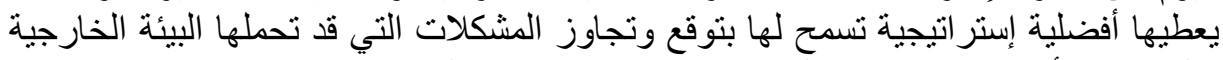

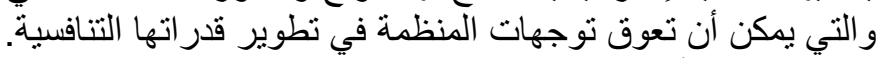

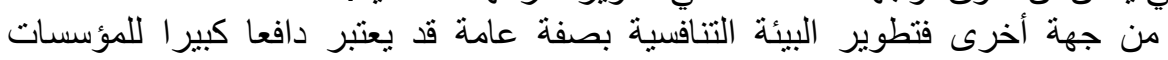

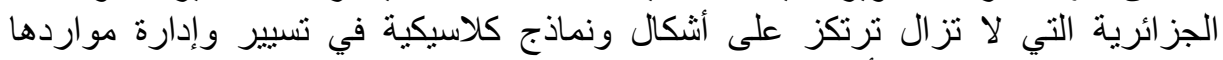

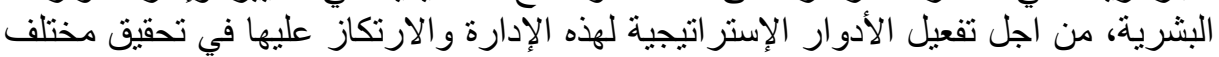

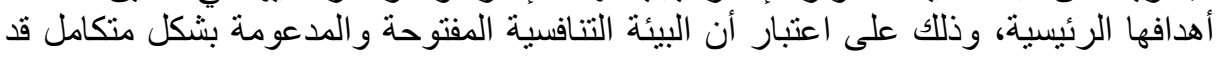

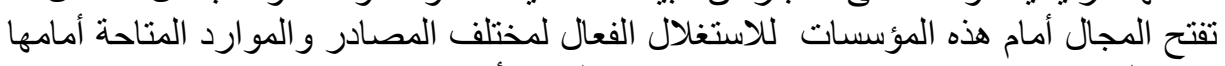

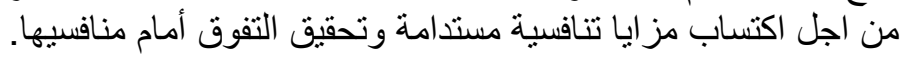

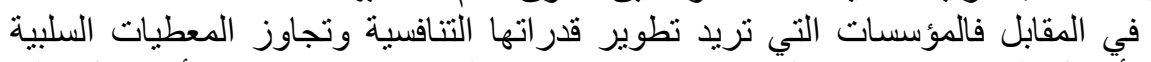

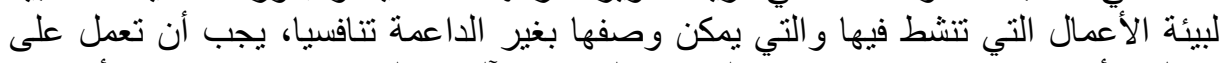

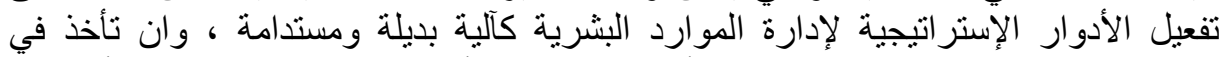

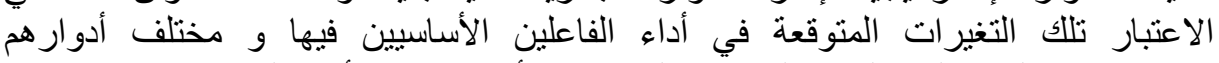

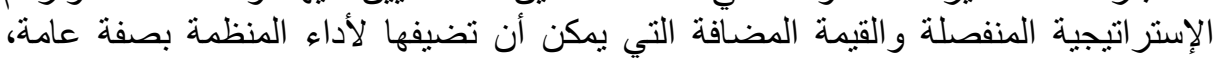

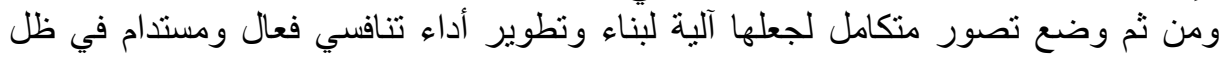

مختلف التحديات الحديثة الني توجهرا المنظمة. 


\begin{tabular}{|c|c|c|}
\hline الاستر اتيجيات التنافسية & & \\
\hline إستر اتيجية التقدير & نادرة & 象 \\
\hline التكلفة & القيمة & $\bar{~}$ \\
\hline التركيز & التقليد & 3 \\
\hline بناء الإستر اتيجية وفق منظور المواءر الداءلية & الاستربتم التيجي & 武 \\
\hline
\end{tabular}

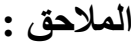

جدول رقم 01 ـ علاقة مؤشرات الموارد البثرية التنافسية بالاستراتيجيات التنافسية

المصدر: من إعداد الباحث

\begin{tabular}{|c|c|c|}
\hline الأدوار الحديثة لإدارة الموارد البشرية في دعم التنافسية & & \\
\hline التدريب/ امتلاك الكفاءة/ تطوير المعارف & القيمة & 3 \\
\hline الثقافة التنظيمية / التحفيز & الندرة & 宣 \\
\hline /أنظمة الأجور/الو لاء التنظيمي & التقليا & 7. \\
\hline 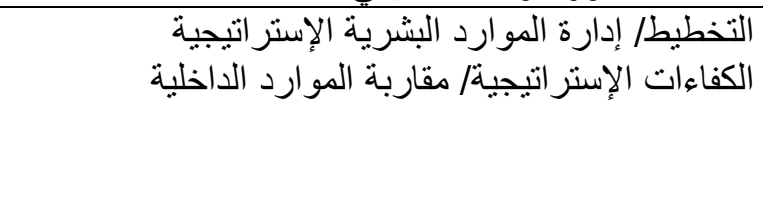 & الاسترئم اتيجي & 清 \\
\hline
\end{tabular}

جدول رقم (01) أهمية الأدوار الحديثة لإدارة الموارد البشرية في تطوير مؤشرات الموارد

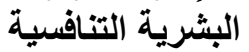

المصدر: من إعداد الباحث التئن

\begin{tabular}{|c|c|c|}
\hline الاستراتيجيات التنافسية & & \\
\hline إستر اتيجية التميز / إستر اتيجية التكلفة & الربحية & 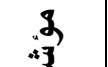 \\
\hline إستر اتيجية التميز / إستر اتيجية التركيز & الحصة السوقية & \\
\hline إستر اتيجية التكلفة & التكلفة & ? \\
\hline إستر اتيجية التميز & الإنتاجية الكلية & : \\
\hline
\end{tabular}

المصدر: من إعداد الباحث 

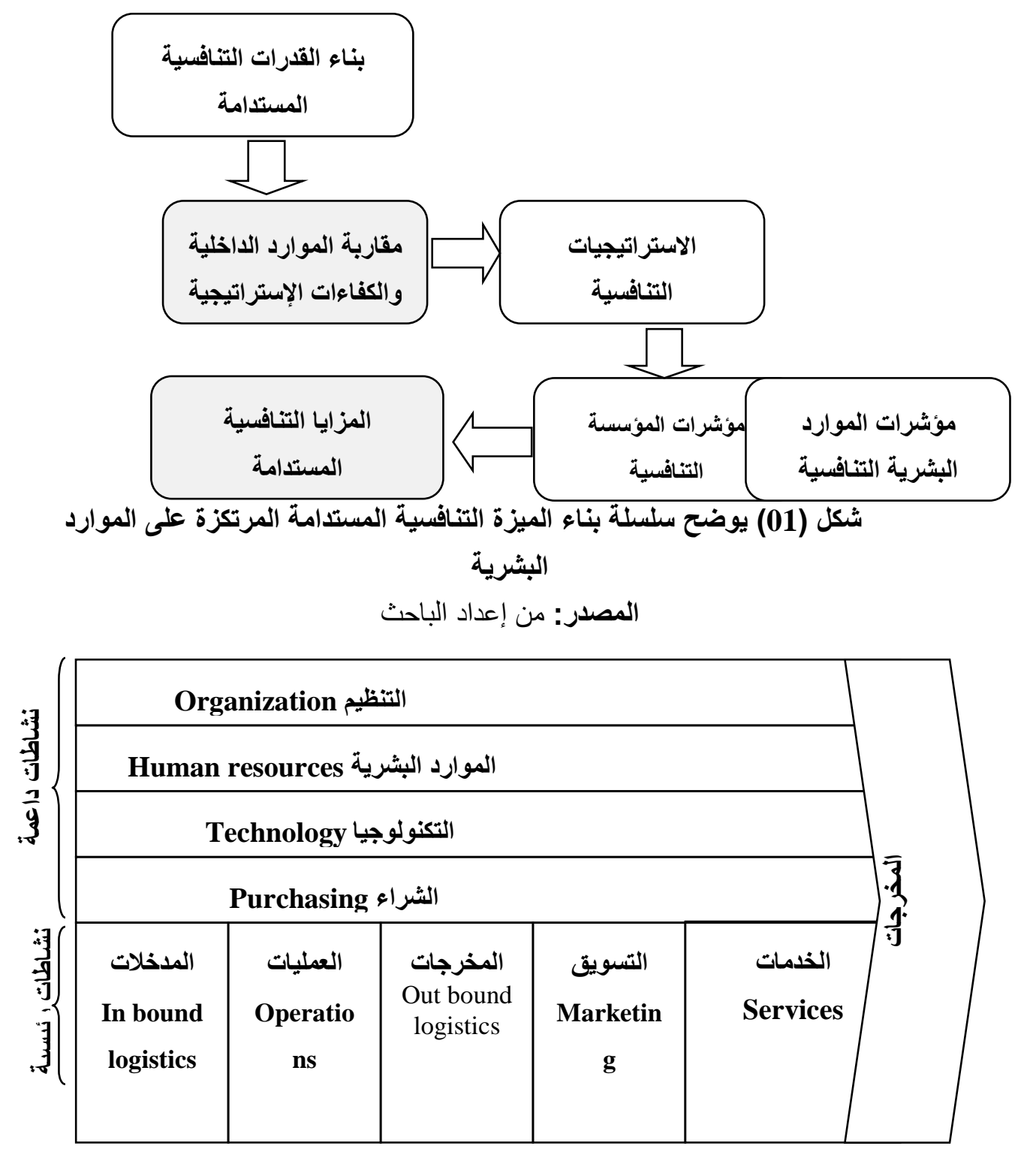

شكل رقم05: نموذج سلسلة القيمة

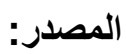

Jean louis magakian, marielle audrey payaud,100 fiches pour comprendre la stratégie d'entreprise, breal, 2007,P124 


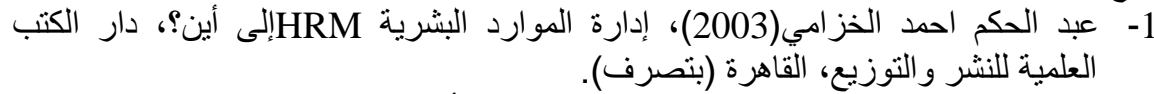

2- محد سرور الحريري، (2012)، الإدارة الحديثة الأسس العلمية والتطبيقية، دار البداية، عمان الأردن، صبرون صنيري.

3- سهيلة محمد عباس(2003)، إدارة الموارد البشرية، دار وائل للنشر، عمان الأردن،

ص27.

4- عاطف غيث ترجمة إبراهيم جابر(2012)، قاموس علم الاجتماع الحديث، دار الدعرفة

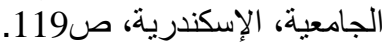

5- باسم أحمد المبيضين، (2011) العلاقات العامة و وأثرها في تعزيز القدرة التنافسبة في

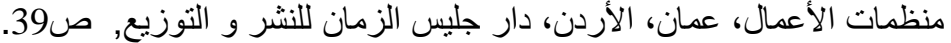

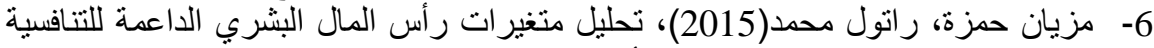

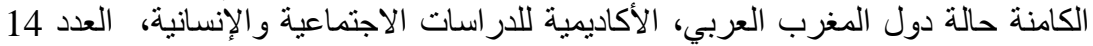

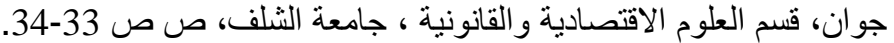

7- راوية حسن، (2004-2003-)، إدارة الموارد البشرية "رؤية مستقبلية"، الدار الجامعية،

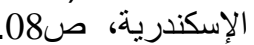

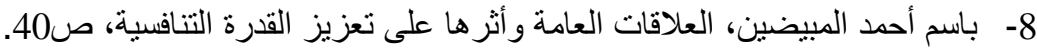
9- مرسي خليل نبيل، (1996) الميزة التنافسية في مجال الأعمال، مركية مركز الإسكندرية، الدار

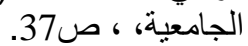

10- Le petit Larousse(1980)librairie larousse ,canada P271

11- سعيد بن عبيد بن نمشة، (2007) إستراتيجية إدارة الموارد البشرية لمواجهة تحديات

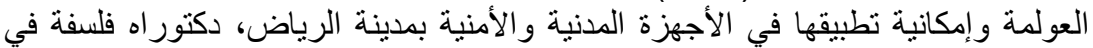

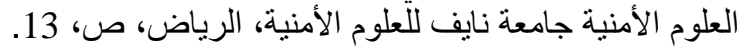

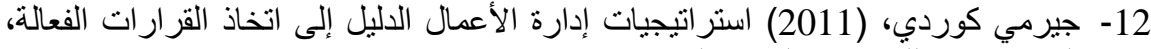

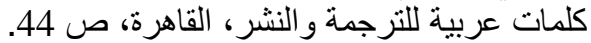

13- Marc Ingham,(1995) Management stratégique et compétitivité .

DEBOECK-WESMAEL S A, BRUXELLES, P35

14- Dan a seni, (2013) analyse stratégique et avantage concurrentiel presses de l'université de quebec, P P 81-82

15- Jean louis magakian, (2007) marielle audrey payaud, 100 fiches pour comprendre la stratégie d'entreprise, breal , P67

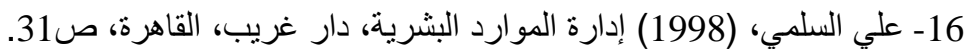

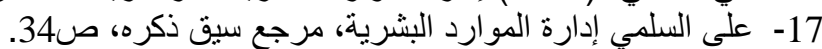

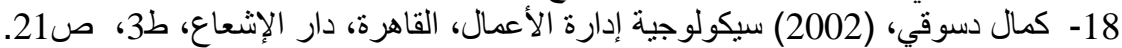

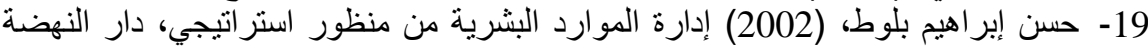

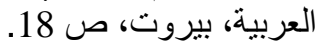

20- سملالي يحضية، (2006) التسيير الاستر اتيجي للموارد البشرية والتميز التنافسي للمؤسسة فئس

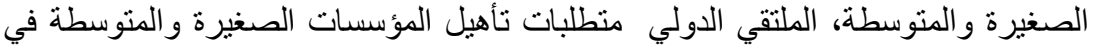

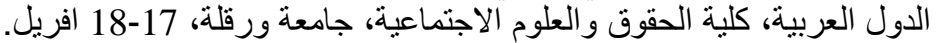

21- اشرف عبد الرحمن الثيمي،(2008) إدارة الموارد البشرية في عصر المعرفة، مؤسسة

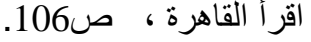

22- سعد علي العنزي، احمد علي صالح، (2009) إدارة رأس المال الفكري في منظمات

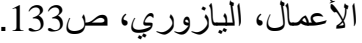

23- الصباغ ، زهير نعيم، (2010) إدارة الموارد البشرية : في القرن الحادي و العشرين :

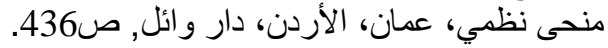

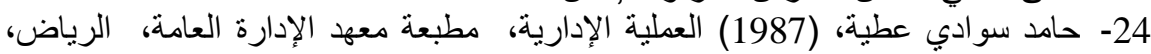

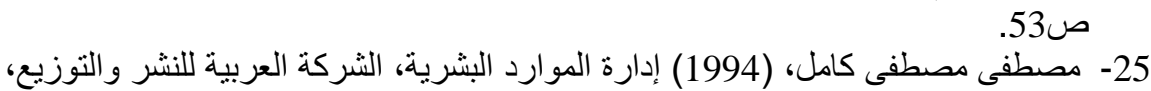

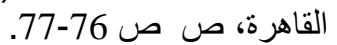

26- طلعت إبر اهيم لطفي، (2007) علم اجنماع التنظيه، دار غريب، القاهرة، ص 123.

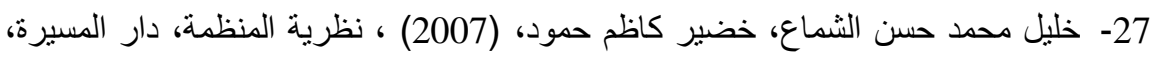




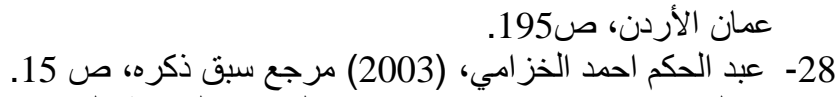

29- عقيلي عمر وصفي، (2009) إدارة الموارد البشرية المعاصرة: بعد إستراتيجي عمان،

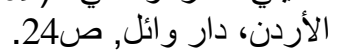

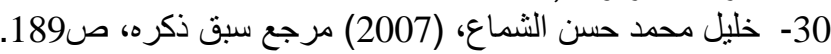

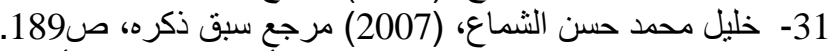

32- ستيفن سيلبجر، (2011) ماجستير إدارة أعمال في عشرة أيام، مكتبة جرير، الرياض، طل صل

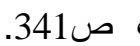

33- Claude Berghmans,(2016) penser et pratiquer les ressources humaines dans l'industrie. L harmattan paris

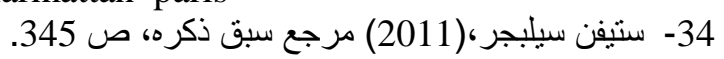

35- ثابت عبد الرحمن إدريس، جمال الدين محمد المرسي، (2006)، الإنية، الإدارة الإستراتيجية،

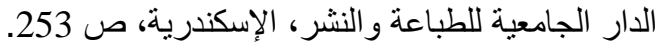

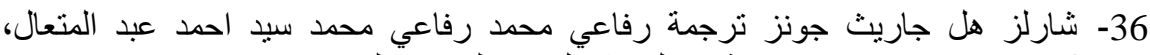

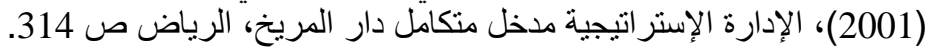

37- https://www.commerce.gov.dz/ar/statistiques/davantage-de-creationsd-entreprises-et-moins-de-radiation-au-1er-trimestre-2017 